\title{
Language Learner Autonomy and Learning Contract: A Case Study of Language Majors of a University in Hong Kong
}

\author{
Mable Chan \\ The Hong Kong Polytechnic University, Hong Kong, China \\ Email: mable.chan@polyu.edu.hk
}

Received 19 January 2015; accepted 10 April 2015; published 15 April 2015

Copyright (C) 2015 by author and Scientific Research Publishing Inc.

This work is licensed under the Creative Commons Attribution International License (CC BY). http://creativecommons.org/licenses/by/4.0/

(c) (i) Open Access

\begin{abstract}
With the aim of developing first year undergraduate students' awareness and ability of autonomous learning, they were asked to do self-access work in an academic English proficiency course through drafting a learning contract outlining their learning objectives and submitting learning evidence regularly in the course of the semester. This study examines the content of the learning contract and the English language learning beliefs reflected from the learning objectives formulated, plus questionnaire results, and determines whether university students in Hong Kong are ready for autonomous learning or not. Based on the findings, the study examines whether Hong Kong university students are ready for autonomous learning, and discusses ways to deal with the challenges which might impede implementation of language learner autonomy in Hong Kong.
\end{abstract}

\section{Keywords}

Autonomous Learning, Learning Contract, Language Learning Beliefs

\section{Introduction}

Language learner autonomy has been and is always one of the significant learning attributes required no matter for secondary or tertiary students in Hong Kong. According to the Education Manpower Bureau (EMB), one of the best teaching practices is the development of self-access centres in secondary schools in Hong Kong (Educational Bureau, 2013: p. 20) which aims to shift from a teacher-centred learning approach to one of student-centred, and "to focus on the needs of individual students, allowing them to work at their own level and reach their own potential [...]". In the curriculum and assessment guide for secondary 4 - 6 students (the Curriculum Development Council \& the Hong Kong Examinations and Assessment Authority, 2007), recommendations were 
given concerning how to promote independent learning in secondary students. A project team consisting of curriculum development officers of EMB, and language consultants was then formed and assisted in establishing a number of self-access centres in secondary schools in Hong Kong (Miller et al. 2007). While the Hong Kong government interprets autonomous learning as mainly students having self-access work in a self-access centre, autonomous learning at the tertiary level has expanded to virtual self-access centres, and other resources for selflearning such as message boards, discussion forums and websites that promote self-learning (Gui \& Northern, 2013). Obviously, the notion of language learner autonomy is not confined to learning that takes place in a selfaccess centre.

Attention and interest in language learner autonomy research has been increasing since mid-1970s. According to Holec (1981, p. 3), learning autonomy is "the ability to take charge of one’s learning”. Littlewood (1991, p. 4) defined it as "a capacity—for detachment, critical reflection, decision-making and independent action”. In Benson's (2001, p. 47) words, it is "the capacity to take control of one's own learning”. Though the wordings are different, these definitions all point to the same idea about the learner's competence and willingness of being responsible for his/her own learning, specifically about what to learn, when to learn and how to learn.

Emphasis on students' independent learning ability is getting increasing attention at the tertiary level and raising their awareness of the importance of autonomous learning ability is key to their success in the course of their study. With the aim of developing first year students' awareness and ability of autonomous learning, they were asked to do self-access work in an academic English course through drafting a learning contract outlining their learning objectives in terms of the four macro skills in English and submit evidence of their self-access work regularly in the course of the semester. This study reveals what university students do when given the chance of learning autonomously though examining the content of the learning contract and the English language learning beliefs reflected from the learning objectives formulated. In addition to the questionnaire results, this study discusses if tertiary students are ready for autonomous learning or not.

The literature review below outlines the different levels of language learner autonomy, importance of examining language learning beliefs, the correlations between language learning beliefs, autonomous learning and language learning outcome. Research questions of this study are outlined at the end of the review.

\section{Literature Review}

\subsection{Levels of Language Learner Autonomy}

There are many different definitions of language learner autonomy but it is generally agreed that language learner autonomy is a matter of degree, implying a progression from lower to higher levels of autonomy (Benson 2007). In Nunan (1997, p. 195), autonomy is a model of five levels of "learner action": "awareness", "involvement", "intervention", "creation" and "transcendence". At the awareness level, for example, learners are "made aware of the pedagogical goals and content of the materials ... and identify their own preferred learning styles/strategies". At the transcendence level, learners are required to apply: "make links between the content of classroom learning and the world beyond". In other words, there might be students who are more autonomous and others who are less. Something else we need to consider is whether we regard autonomy as a kind of stable attribute of learners or it is subject to change depending on different contexts/situations/occasions. How to measure the learners' levels of autonomy is another significant issue to consider.

A distinction is also made between proactive autonomy and reactive autonomy (Littlewood, 1999: p. 75). Proactive autonomy refers to one's initiative in formulating directions: "affirms learners' individuality and sets up directions which they themselves have partially created" whereas reactive autonomy "does not create its own directions, but once a direction has been initiated, enables learners to organize resources autonomously in order to reach their goal”. Though they seem to be different, they actually represent different extents of autonomy and should be regarded as a continuum instead.

\subsection{Importance of Examining Language Learning Beliefs}

Learner beliefs about second language acquisition have been regarded as an important factor shaping the learning process and outcomes (Ellis, 2008). There are different studies which examine different types of language learning beliefs and their correlations with other factors, such as learners' strategy use (Yang, 1999) and learner autonomy (e.g. Cotterall, 1999). 
A number of affective factors have been introduced in the literature, and successful language learners seem to possess similar traits. Some of the most frequently examined factors include Brown's (1994) personality factors (i.e. self-esteem, risk-taking, inhibition, anxiety, empathy, extroversion), learning styles (Oslund, Kolb, \& Rubin, 2001) and learning strategies (Rubin, 1975, 1981; Oxford, 1990). There seems to be consensus that attitudes to learning and language learning beliefs which determine them, have a "profound influence..... on learning behaviour" (Cotterall, 1995: p. 195) and consequently on learning outcomes.

According to Rubin and Thompson (1982), there are 12 features for a good language learner, which concern what a good language learner do (e.g. finding their own way, organizing information about language, making errors work, using linguistic knowledge to learn a second language, learning production techniques, etc). Underlying such behaviour is actually the belief of second language learners. For example, the behaviour of "finding their own way" is related to the belief of whether passive or active learners benefit learning. The strategies adopted also reflect the learners' perception of what is the most useful in language learning. Ellis and Sinclair (1989) also identified a list of features for a good language learner, and they are categorized into 7 points, including being self-aware, inquisitive and tolerant, self-critical, realistic, willing to experiment, actively involved and organized, which shared some of the features in Rubin and Thompson (1982).

It can be concluded that one's belief is in fact the single construct which affects learners' motivation, use of strategies, doing or not doing something in language learning. Given the important role of such, a number of other studies have been done to examine the language learning beliefs of students and teachers, if there is a gap between students' beliefs and teachers' and how the gap can be bridged.

The pioneer of research investigating learner beliefs is Professor Elaine Horwitz. According to Horwitz (1988), foreign language students reported a much higher preference for grammar and vocabulary learning exercises than their teachers. The implication is that there might be a mismatch in students' and teachers' views about class activities, and students might not be willing to participate in communicative activities. This finding still emerges in recent studies about learners and teachers' belief about language learning.

In Kern (1995), the beliefs of French students and teachers seem to be consistent, but learners were found to be over-optimistic or unrealistic about the length of time it takes to become fluent in a foreign language. This finding is consistent with that obtained in Peacock (1999). Hong Kong tertiary students generally underestimate the time it takes for them to be fluent in English. This leads to negative impact as at the end of the period when they think they can master the language but they fail, they will become frustrated, and will lose confidence.

Taiwan EFL students (Banya \& Cheng, 1997) are more optimistic in language learning, and the higher achievers tend to regard English as less difficult. They find grammar and translation the most important in learning English. A comparison was also made in the study between Chinese and US learners of English. It was reported that the Chinese students use more compensation strategies; they memorize vocabulary and grammar for accuracy and proficiency and they are too concerned about error correction. They stress the importance of speaking with an excellent accent and are motivated instrumentally.

Peacock (1999) studied the Hong Kong college students and teachers and found that students focus significantly greater on vocabulary, grammar and pronunciation than teachers did. There are some other beliefs which are detrimental to their learning of English. For example, subjects were asked to express their extent of agreement to the statement about the number of hours they expected to spend in a day to become fluent in a foreign language (i.e. If someone spent one hour a day learning a foreign language, to become fluent, it would take him/ her a) less than a year, b), 1 - 2 years, c) 3 - 5 years, d) 6 - 10 years). The results show that most learners chose the category of $3-5$ years. Peacock found that those who underestimate the difficulty of learning a foreign language have lower English proficiency level, which might be a result of their underestimation of the difficulty and the frustration resulted. There are other statements about learners' perception of learning English (i.e. learning a foreign language is mainly a matter of learning a lot of grammar rules; It is important to speak a foreign language with an excellent accent.). The majority of subjects agreed with both statements about the importance of learning grammar and having the native accent. In Siebert, Wilke, Delva, Smith, and Howell (2003), the subjects were college students in the States, and it was found that students emphasize pronunciation, grammar, vocabulary learning and also translation. It seems that ESL learners focus on similar areas in learning English, despite their different nationality backgrounds.

The different perception of students and teachers can be found in Davies (2003). The subjects were college students in Macao. Students had strong belief than teachers in a number of areas: teachers should correct students when they made grammatical mistakes in order to prevent the formation of bad habits; most of the mis- 
takes L2 learners made were a result of L1 interference; teachers should present grammatical rules one at a time and students should practise each of these before moving on; and teachers should use materials that expose students only to those language structures that have already been taught.

Hawkey (2006)'s study is mainly about the perception of students and teachers towards language learning activity (e.g. grammar, listening to teacher talking, pair work, etc.). The subjects were Italian students. It was found that there was a mismatch in students' and teachers' perceptions about English learning activities. Students favor more grammar and teachers more discussion and pair work. The findings about the Iranian students (EslamiRasekh \& Valizadeh, 2004) seem to be different from those in Hawkey's. Students were found to have a higher preference for communicative activities. They also have the same problem of underestimating the difficulty of the English language in comparison with their teachers.

\subsection{Language Learning Beliefs and Language Learner Autonomy}

By examining the correlation between language learning beliefs and language learner autonomy, we might be able to investigate whether there exists a positive relationship between autonomous learners and positive language learning outcome.

Six factors were identified in Cotterall (1995) concerning different dimensions indicating whether learners are ready for autonomous learning or not. They are a) role of the teacher; b) role of feedback; c) learner independence; d) learner confidence in study ability; e) experience of language learning; and f) approach to studying. A subsequent 90 -item questionnaire was developed (Cotterall, 1999) based on the first five factors to examine further learners' perception of the different aspects and their readiness for autonomous learning. Subjects of the study were 131 learners of English from 19 different countries enrolled in an English course at Victoria University of Wellington.

Based on the extent of agreement towards a number of statements concerning the role of the teacher, there was evidence showing that learners were willing to take up responsibility for their own learning, which is consistent with how autonomy is defined in the literature. Regarding their perception about the nature of learning, most subjects believed that making mistakes is part of the language learning process, which is regarded by Wenden (1991) as a significant component of language autonomy. Subjects also believed that they need to learn language rules before communicating, reflecting their desire to use the language after class. Another indicator showing readiness of autonomous learning is related to the subjects' willingness of using a variety of language learning strategies even when they do not have knowledge about these strategies (e.g. setting goals; planning their learning). Findings also show that the subjects were able to use six of the eight language learning strategies specifically about managing one's own learning, involving cognitive (e.g. I know how to find my own ways of practicing); social (e.g. I know how to ask for help); and metacognitive (e.g. I know how to identify my strengths and weaknesses as a learner). According to the writer (1999, p. 21), these strategies "represent important knowledge and behavior for learners who wish to assume responsibility for aspects of their language learning".

Despite these possible indicators showing a tendency of autonomous learning, it was also found that the subjects failed to use strategies that help monitor and evaluate their learning, and this might be a result of their lack of self-efficacy, which, unfortunately is essential to an autonomous learner. Breen and Mann (1997, p. 134), for example, believe that autonomous language learners should have "a robust sense of self".

\subsection{Challenges Introducing Autonomous Learning}

To implement autonomous learning is not an easy task. According to Benson (2000), there are four categories of constraints when implementing language learner autonomy, including a) policy constraints (broad policies on language education); b) institutional constraints (e.g. rules and regulations, curriculum, examinations); c) conceptions of language (i.e. dominant perception of the target language) and d) language teaching methodologies (assumptions about how languages should be taught). In Little (2009), the three challenges identified are: a) teachers' doubt about whether autonomous learning can be effectively carried out; b) lack of teachers' expertise; and c) exam/curriculum/textbook constraint.

Borg (2011) examined the challenges and the subjects were about 62 English language teachers of a language centre in Oman. The teachers identified a few factors which might impede the implementation of language learner autonomy. They include a) learner factors (e.g. their lack of motivation and skills for learning indepen- 
dently); b) institutional factors (e.g. overloaded curriculum; not enough resources for promoting language autonomy); and c) teacher factors (e.g. lack of teacher autonomy; low expectations of what learners can achieve). It seems that perceptions of teachers, learners and policy-makers do play a significant role in making autonomous learning happen.

\subsection{Significance of the Study}

Findings in the literature show clearly that language learning beliefs, language learner autonomy and language learning outcome are inextricably correlated. A case study examining language learner autonomy of students studying at a tertiary institution in Hong Kong and ways to overcome the challenges in order to develop autonomous learners is thus of great importance. There are three research questions in this study:

- What are the common learning objectives formulated by university students when given the chance to do self-access work?

- What kind of language learning beliefs/attitude can be reflected from the learning objectives formulated?

- What does the case study tell us about language learner autonomy? Are university students ready for independent learning?

\section{Methodology}

Given the close association between language learning attitude and language learning outcome, this study aims at investigating the self-access work of Cantonese ESL learners, specifically year 1 language major students through an examination of the learning contract assignment which requires students to set some English language learning objectives and carry out self-access work in the course of the semester. Based on the learning objectives formulated by the students and a questionnaire examining their language learning beliefs and language autonomy, the research questions can well be addressed.

\subsection{Subjects}

Subjects were 57 students aged from 19 - 22 majoring in English offered by Department of English (ENGL) at The Hong Kong Polytechnic University. They were studying two academic proficiency courses titled English for Advanced Academic Communication (ENGL216) and English for Advanced Academic Writing (ENGL217) when being asked to work on a learning contract assignment for assessment purposes. There were 44 students (2 classes) taking ENGL216 in the first semester and 57 students taking ENGL217 (13 new students) in the second semester.

\subsection{Methods and Data Collection}

In order to examine what Hong Kong university students do when given the opportunity to learn independently, the language learning beliefs reflected and whether they are autonomous learners or not, a learning contract assignment was developed and a questionnaire was also designed.

A learning contract is an agreement between a teacher and a learner. According to Little (2009: 224), there are three pedagogical principles a teacher needs to observe: a) "learner involvement: to involve learners fully in planning, monitoring and evaluating their own learning"; b) "learner reflection: to help learners to reflect continuously on the process and content of their learning and to engage in regular self-assessment"; c) "target language use: to ensure that the target language is the medium as well as the goal of learning”. In this study, a learning contract is about setting English learning objectives and the means to achieve the objectives (please refer to Figure 1). In taking ENGL216 in the first semester, students were asked to formulate two learning objectives based on their weaknesses in the four English macro skills (i.e. listening, reading, writing, speaking), and submit evidence in the course of the semester to show what they have done/achieved. They were also asked to reflect on their process in the middle of the semester and submit reflective essays for a few times reflecting on their performance and the work done so far (though reflective essays are not examined in this study). In the second semester, they were required to work on grammar only. Though this is an assessed task, the learning contract and the objectives formulated are still regarded as a reliable indicator reflecting what learners find important in the learning of English (i.e. their language learning beliefs). The measures they used to achieve their learning objectives could also reflect what they think should be done in order to address the objectives effec- 


\section{ENGL216 (BAESP) \\ Leaming Goals and Contract (2010-2011)}

My language learning goals for this semester are to: (Everal)

1. Writing

2. Speaking

My plans for achieving these goals are given below:

\begin{tabular}{l|l|l}
\hline The Goal How I plan to When J will do the & How
\end{tabular}

\begin{tabular}{|c|c|c|c|}
\hline 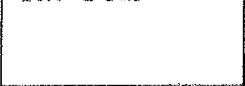 & achieve this goal.... & work......... & $\begin{array}{l}\text { long it will } \\
\text { take....... }\end{array}$ \\
\hline $\begin{array}{l}\text { 1. Learn more } \\
\text { professional } \\
\text { vocabularies from } \\
\text { news. }\end{array}$ & $\begin{array}{l}\text { >read more newspaper. } \\
\text { (Go to CILL for the free } \\
\text { "Standard", and buy } \\
\text { SCMP sometimes) } \\
\text { >watch TVB/ATV news. } \\
\text { (improving my listening } \\
\text { skills too) } \\
\text { > write some short article } \\
\text { by using words l leart. }\end{array}$ & Today & $\begin{array}{l}>\text { Everyday, } 1 \text { hour. } \\
\text { > Everyday, } 30 \text { minutes. } \\
\text { (TVB:15 mins. ArV: } 15 \text { mins) } \\
\text { > Every week, once a week. }\end{array}$ \\
\hline $\begin{array}{l}\text { 2. Learn more about } \\
\text { pronunciation, } \\
\text { listening skills and } \\
\text { diction of words. } \\
\text { Trying to use } \\
\text { appropriate words } \\
\text { in the paragraph. }\end{array}$ & $\begin{array}{l}>\text { Watch movie twice a } \\
\text { month } \\
>\text { write some movie } \\
\text { review, and journals } \\
\text { about what I learnt from } \\
\text { the movie. } \\
>\text { read more movle } \\
\text { review. }\end{array}$ & Every weekend & Twice a month. \\
\hline $\begin{array}{l}\text { 3. improving my } \\
\text { English Speaking } \\
\text { competence. } \\
\text { Improving my } \\
\text { speaking skills, } \\
\text { pronunciation, } \\
\text { and increase my } \\
\text { vocabulary } \\
\text { database. }\end{array}$ & $\begin{array}{l}>\text { Speak more English in } \\
\text { front of people. } \\
\text { > Trying out different kind } \\
\text { of English speaking } \\
\text { activities. Such as group } \\
\text { discussion, or giving } \\
\text { some speeches. } \\
\text { > Joined the SAT in CILL. }\end{array}$ & Today & $\begin{array}{l}\text { Anytime, } \\
\text { no regular schedule. }\end{array}$ \\
\hline
\end{tabular}

I agree to work toward these goals to the hest of myefforts.

$$
7 / 10.12010 \text { (Date) }
$$

(Signature)

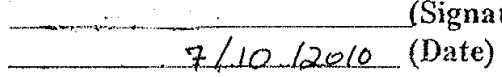

1

Figure 1. Example of a learning contract.

tively. During the whole process of doing this learning contract assignment, students are reminded of the importance of doing self-access work to improve their weaknesses in English learning, and were told clearly that the assessment criteria concerned not the quantity of work done but whether what they have done can effectively help address the learning objectives formulated. There does not seem to be any case showing students' intention of working on something easy in order to get a high grade. 
A questionnaire was also developed to examine university students' beliefs about language learning and their readiness for autonomous learning (see Appendix I) more directly. There were three parts in the questionnaire. The first part was about students' beliefs and attitudes towards language learning and specific learning objectives using likert scale (1 - 5 representing different levels of agreement). Concerning beliefs about language learning, the statements were adopted from BALLI (Peacock, 1999). There were also statements regarding subjects' attitude towards specific learning objectives in listening, reading, speaking and writing based on the learning objectives formulated by the subjects in the learning contract. The second part included statements adopted from Wenden (1991) about students' attitude towards self-access work. Subjects were asked to express agreement or disagreement to statements such as "One problem with studying English is that classes are at fixed hours" and "If I had the right materials, I'd prefer to spend some time studying alone". The last part of the questionnaire asked open-ended questions for the subjects to express freely what they think about autonomous learning. There were five questions as follows:

- Was the idea of self-access learning introduced in your secondary education? How was the idea introduced? How did you learn English in a self-access way?

- Do you consider yourself capable of learning English through ways like learning contract? Are you able to implement the learning contract as what are stated in your learning contract? Why or why not?

- Are you ready for learning independently? Why or why not?

- Does submitting learning evidence help you better fulfill the tasks stated in the learning contract? Why or why not?

- By the end of this learning contract, will you continue to use learning contract as a learning approach to improve your English language proficiency? Why or why not?

\section{Findings}

\subsection{Learning Contract and Learning Objectives Formulated}

44 students enrolled in the course English for Advanced Academic Communication (ENGL216) in the first semester of the 2010-2011 academic year, and 57 students in the course English for Advanced Academic Writing in the second semester. Both courses had a self-access component and students were required to work on a learning contract as one of the assessments (15\%). Below reports the learning objectives formulated by the students in both courses.

In the first semester, students were asked to do self-access work to improve their weaknesses in English learning. Based on students' self-assessment and understanding of their own strengths and weaknesses in English learning, students were asked to fill in the learning contract outlining the learning objectives they want to work on, the measures and frequency of the self-access work. After receiving feedback from the teacher (see samples of feedback in Appendix II), students finalize their learning contract and work on it accordingly.

As shown in Table 1, there were six areas students worked on for their learning contract in the first semester, and among which speaking (86.4\%) is what students are concerned most, followed by vocabulary (47.4\%) and writing (45.5\%). In terms of speaking, there were 58 specific objectives falling into 5 categories, of which confidence/language competence is specifically what students want to work on. For vocabulary, there were 25 objectives, which were categorized into 4 areas with expanding vocabulary size their priority. Regarding writing, there were 24 objectives, specifically divided into 8 areas, of which appropriate use of words is their main concern. For listening, 17 specific objectives were formulated, and students are most interested in comprehending the conversations of native speakers. For reading, there were 11 objectives formulated and reading speed is students' main concern. Finally, in terms of grammar, 9 objectives were formulated, and an overall improvement in grammar is most expected.

In the second semester, students taking ENGL217 were asked to focus on grammar in the learning contract. Despite this requirement, some students still worked on other areas like writing, speaking and vocabulary. There were 57 students working on the learning contract in the second semester, and most students worked on grammar expectedly (87.7\%, 50 students out of 57$)$, followed by vocabulary (64.9\%), writing (14\%) and speaking (3.5\%). Students took the subject Lexical Study in semester one and maybe this is the reason why they seem to be more interested in vocabulary learning in the second semester. In terms of grammar, 64 objectives were found. Students seem to be concerned about tense most (23 objectives about correct use of tense) (see Table 2 for details). For vocabulary learning, there were 39 objectives and most of them concerned collocation learning 
Table 1. Learning objectives for the first semester (2010-2011).

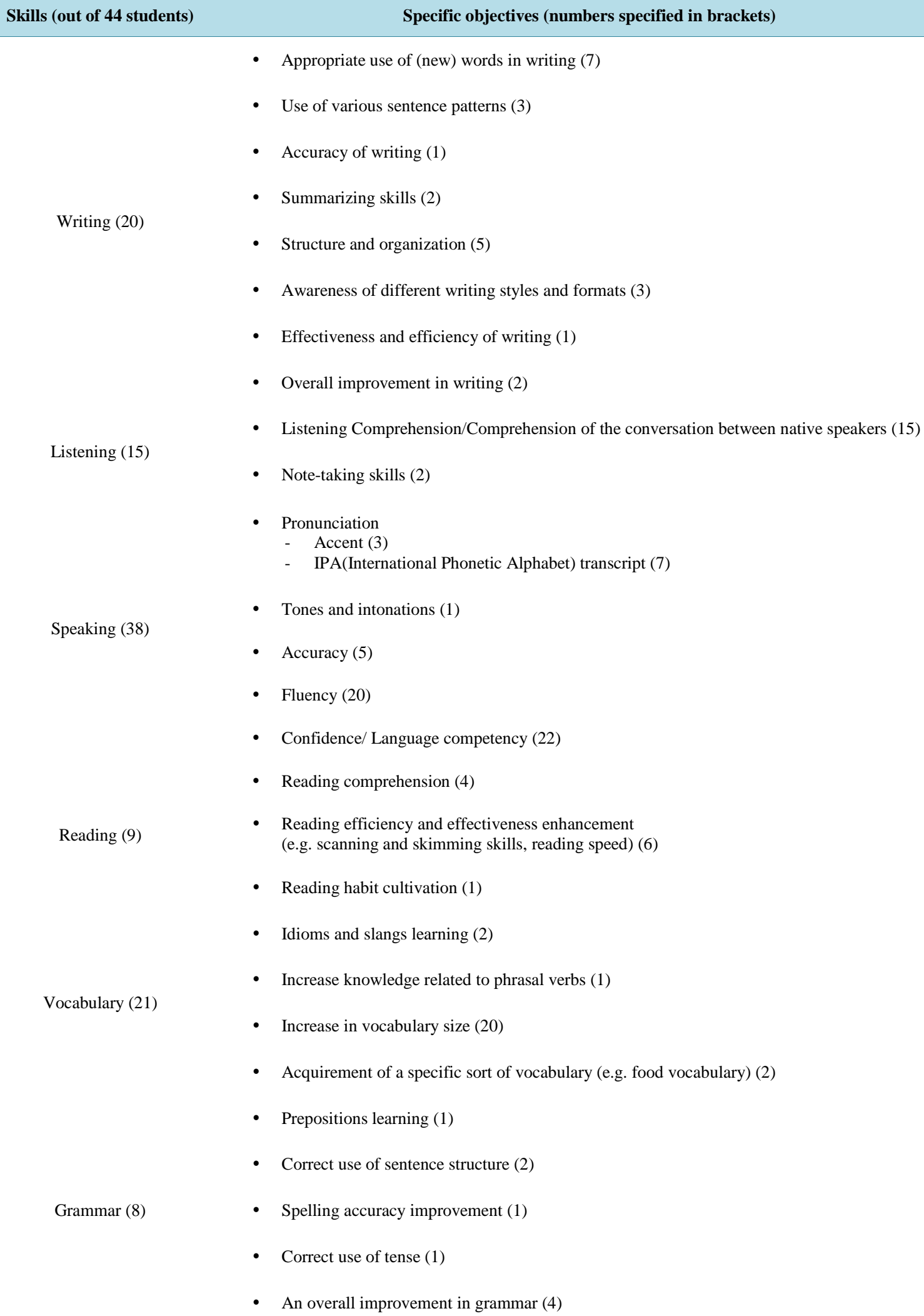

- Reading habit cultivation (1)

- $\quad$ Idioms and slangs learning (2)

- Increase knowledge related to phrasal verbs (1)

- Increase in vocabulary size (20)

- Acquirement of a specific sort of vocabulary (e.g. food vocabulary) (2)

- Prepositions learning (1)

- Correct use of sentence structure (2)

- $\quad$ Spelling accuracy improvement (1)

- Correct use of tense (1)

- An overall improvement in grammar (4) 
Table 2. Learning objectives for the second semester (2010-2011).

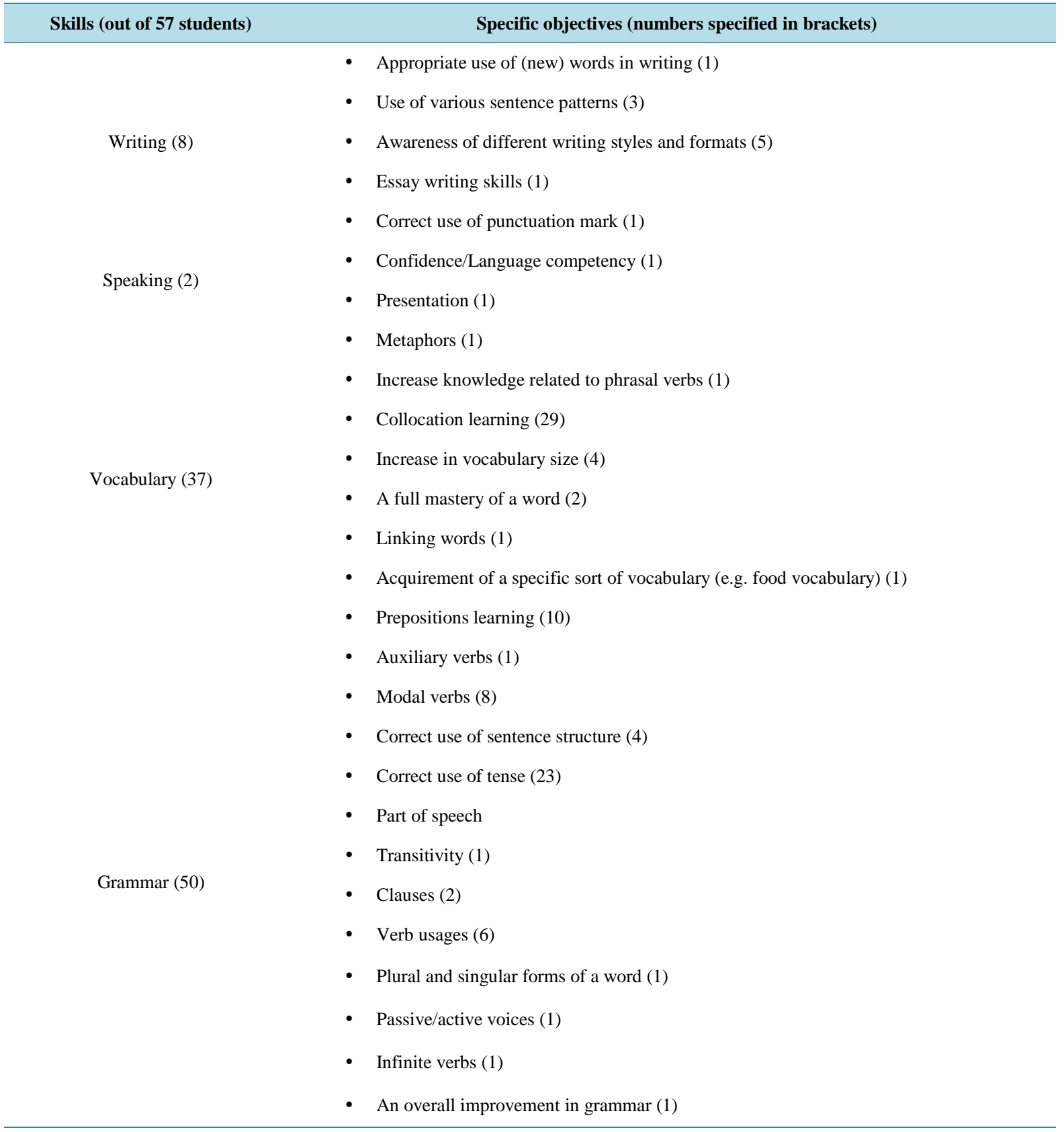

(29) and prepositions (10). For speaking, there were two objectives, one about improving confidence/language competency and another about presentation skill.

\subsection{Questionnaire Results}

\subsubsection{Beliefs about Language Learning}

Figure 2 shows the results of Part I concerning the subjects' beliefs towards language learning and specific learning objectives. In this section, the subjects were first required to show their extent of agreement to 15 statements mostly taken from BALLI (Peacock, 1999) using a five-point likert scale (5 indicating strongly agree and 1 strongly disagree). There were 52 questionnaires received.

It can be seen that the subjects tend to agree or strongly agree with three of the statements: "I prefer to study 


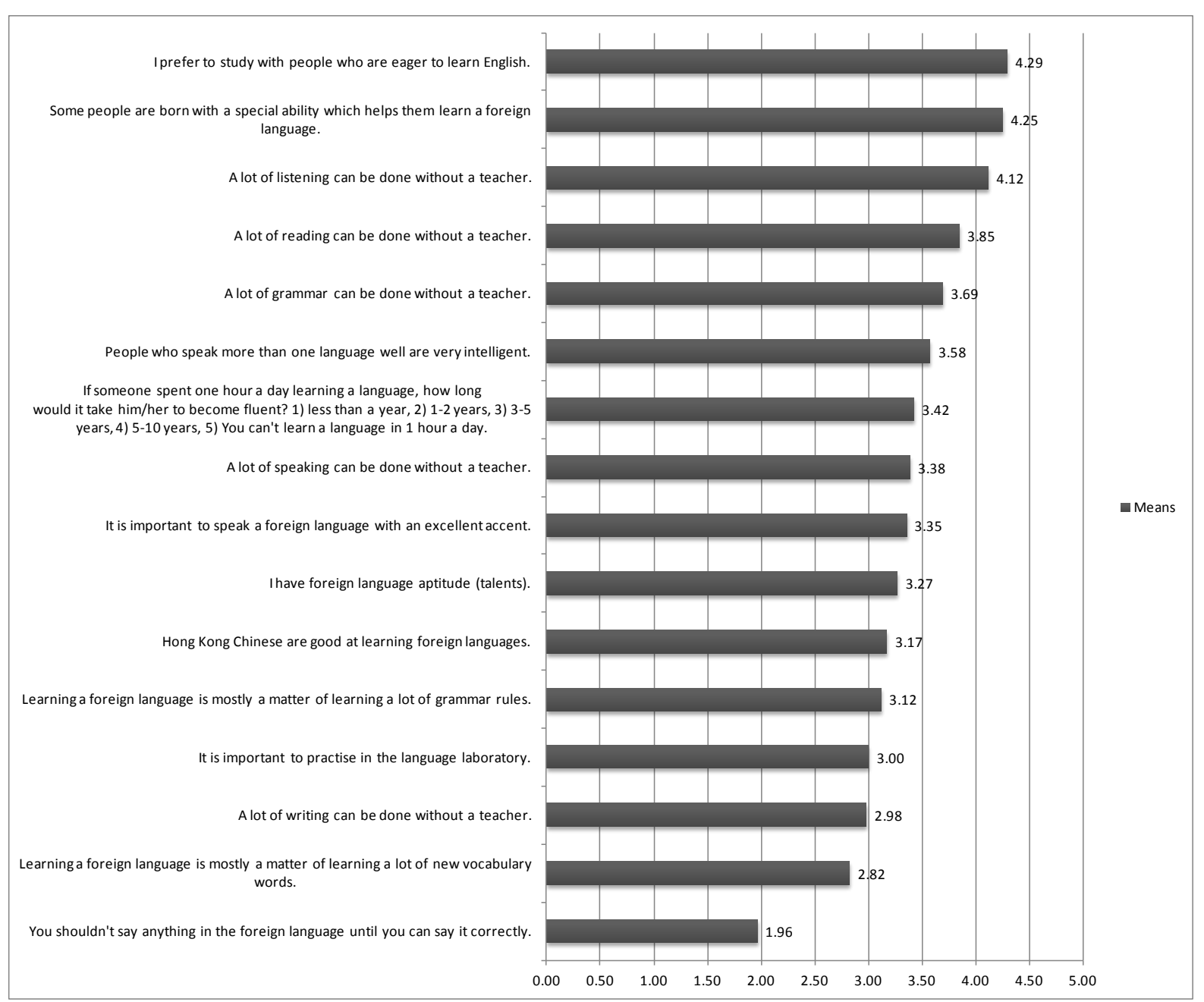

Scale: Strongly Disagree $=1 ;$ Disagree $=2 ;$ Neutral $=3$; Agree $=4$; Strongly Agree $=5$

Figure 2. Subjects’ beliefs towards language learning.

with people who are eager to learn English" (4.29); "Some people are born with a special ability which helps them learn a foreign language" (4.25); "A lot of listening can be done without a teacher" (4.12). There were also three statements the subjects tend to disagree: "You shouldn't say anything in the foreign language until you can say it correctly" (1.96); "Learning a foreign language is mostly a matter of learning a lot of vocabulary words" (2.82); "A lot of writing can be done without a teacher" (2.98). Using generalized linear model: repeated measures, the different means were compared. It was found that the means were significantly different from each other except the pair grammar versus reading (see Figure 3).

Based on the learning objectives developed by the subjects in the learning contract, some statements were also included in the questionnaire to examine the subjects' attitude towards specific learning objectives in terms of listening, reading, writing and speaking (see Figures 4-7). In terms of listening, the subjects agreed or strongly agreed that learning listening skills is about getting the main idea of what others said in English (4.17), and about being able to summarize what others have said (4.06). They did not agree, however, that learning listening skills is about understanding every word said in English (2.38). For reading, they agreed or strongly agreed that learning reading is about getting the main idea of what is read (4.33) and about skimming and scanning (3.67). They did not agree that learning reading skill is about understanding every word of a text in English. In the area of writing, subjects believed that learning English writing is about (a) appropriate use of words (4.37); being able to write logically (4.31); being able to write concisely (4.15); being aware of different writing styles and formats (4.12); the use of various sentence patterns (4.10); using correct grammar (4.00). Subjects tend to dis- 


\begin{tabular}{lllll}
\hline & 2 & $-.423^{*}$ & .096 & .000 \\
& 3 & -.154 & .130 & .242 \\
& 4 & $.712^{*}$ & .144 & .000 \\
& 5 & $.288^{*}$ & .144 & .050 \\
& 1 & $.423^{*}$ & .096 & .000 \\
& 3 & $.269^{*}$ & .114 & .022 \\
& 4 & $1.135^{*}$ & .158 & .000 \\
& 5 & $.712^{*}$ & .133 & .000 \\
& 1 & .154 & .130 & .242 \\
& 2 & $-.269^{*}$ & .114 & .022 \\
& 4 & $.865^{*}$ & .135 & .000 \\
& 5 & $.442^{*}$ & .144 & .003 \\
& 1 & $-.712^{*}$ & .144 & .000 \\
& 2 & $-1.135^{*}$ & .158 & .000 \\
& 3 & $-.865^{*}$ & .135 & .000 \\
& 5 & $-.423^{*}$ & .136 & .003 \\
& 1 & $-.288^{*}$ & .144 & .050 \\
& 1 & $-.712^{*}$ & .133 & .000 \\
& 2 & $-.442^{*}$ & .144 & .003 \\
& 3 & $.423^{*}$ & .136 & .003 \\
\hline
\end{tabular}

${ }^{*}$ The difference is insignificant.

\begin{tabular}{|cc|}
\hline Measure: & Belief \\
\hline Factor 1 & Dependent variable \\
\hline
\end{tabular}

2

3

4

5
A lot of grammar can be done without a teacher.

A lot of listening can be done without a teacher.

A lot of reading can be done without a teacher.

A lot of writing can be done without a teacher.

A lot of speaking can be done without a teacher.

Figure 3. Generalized linear model: repeated measures.

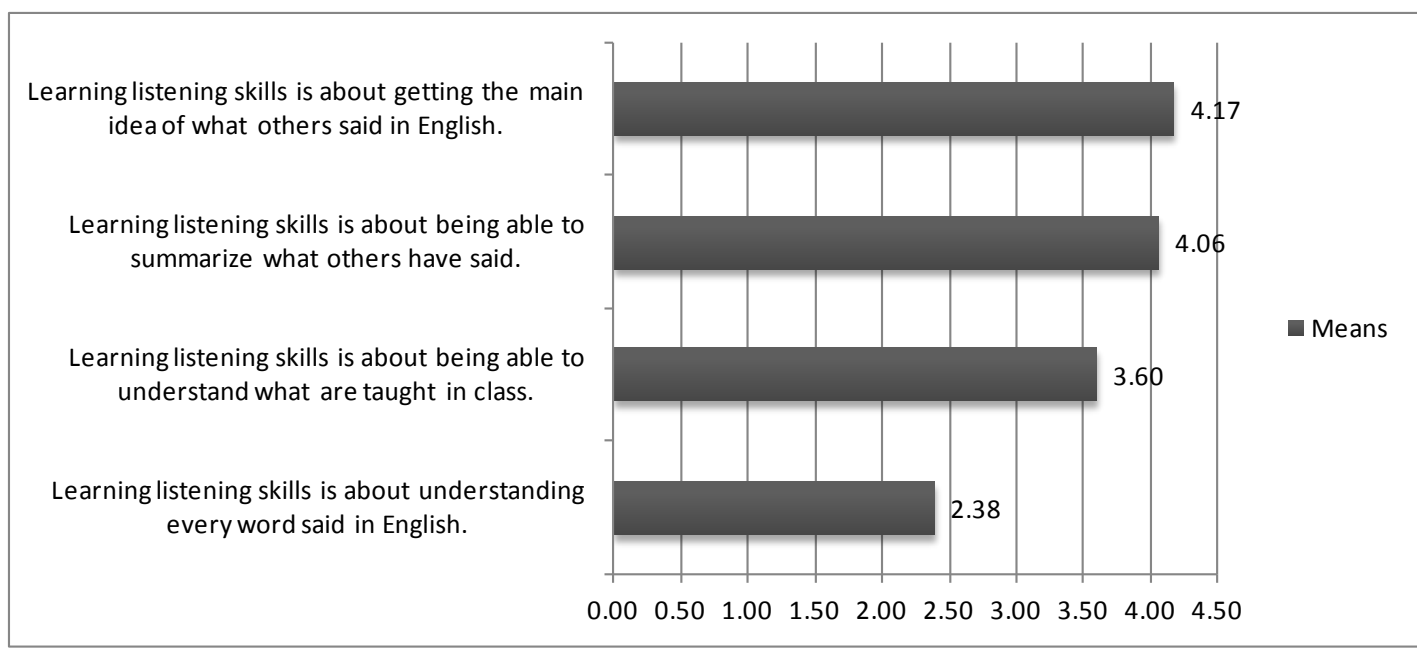

Scale: Strongly Disagree $=1 ;$ Disagree $=2 ;$ Neutral=3; Agree $=4 ;$ Strongly Agree $=5$

Figure 4. Attitude towards learning listening. 


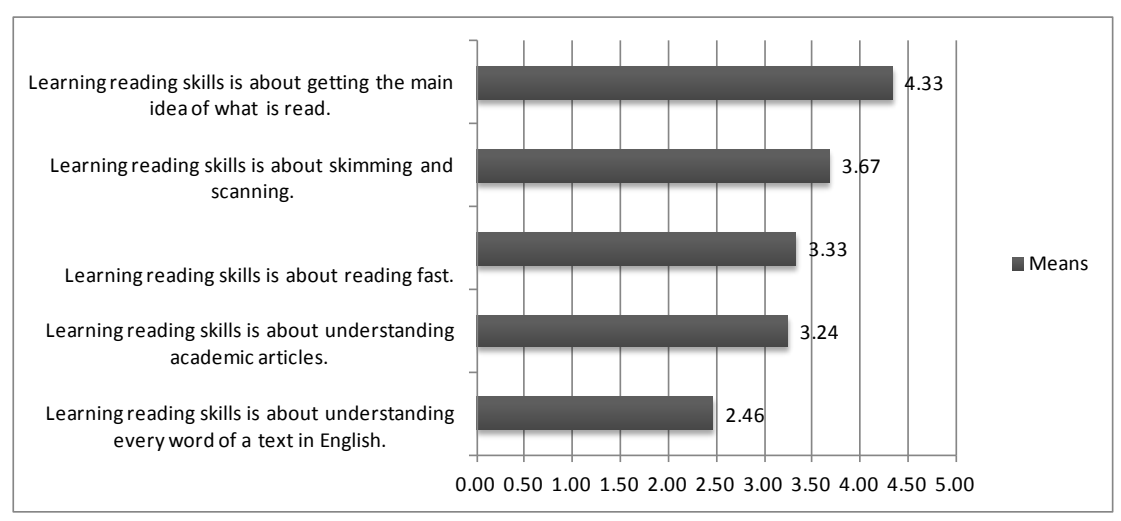

Scale: Strongly Disagree $=1 ;$ Disagree $=2 ;$ Neutral $=3 ;$ Agree $=4 ;$ Strongly Agree $=5$

Figure 5. Attitude towards learning reading.

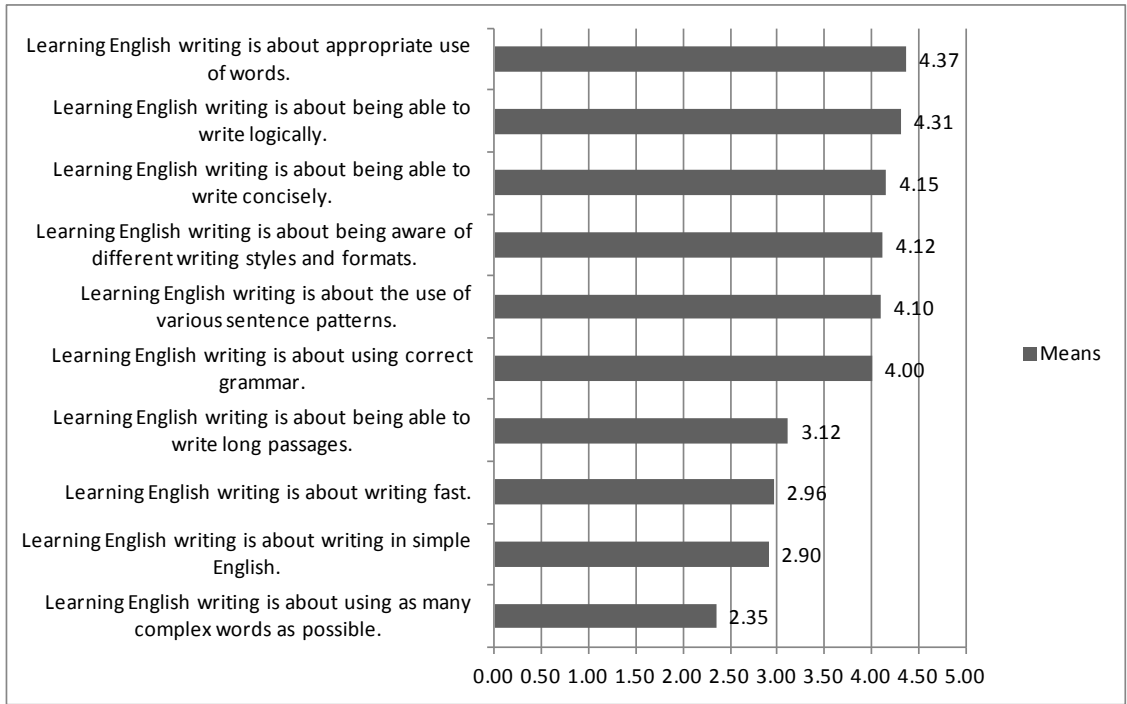

Scale: Strongly Disagree $=1$; Disagree $=2 ;$ Neutral $=3$; Agree $=4$; Strongly Agree $=5$

Figure 6. Attitude towards learning writing.

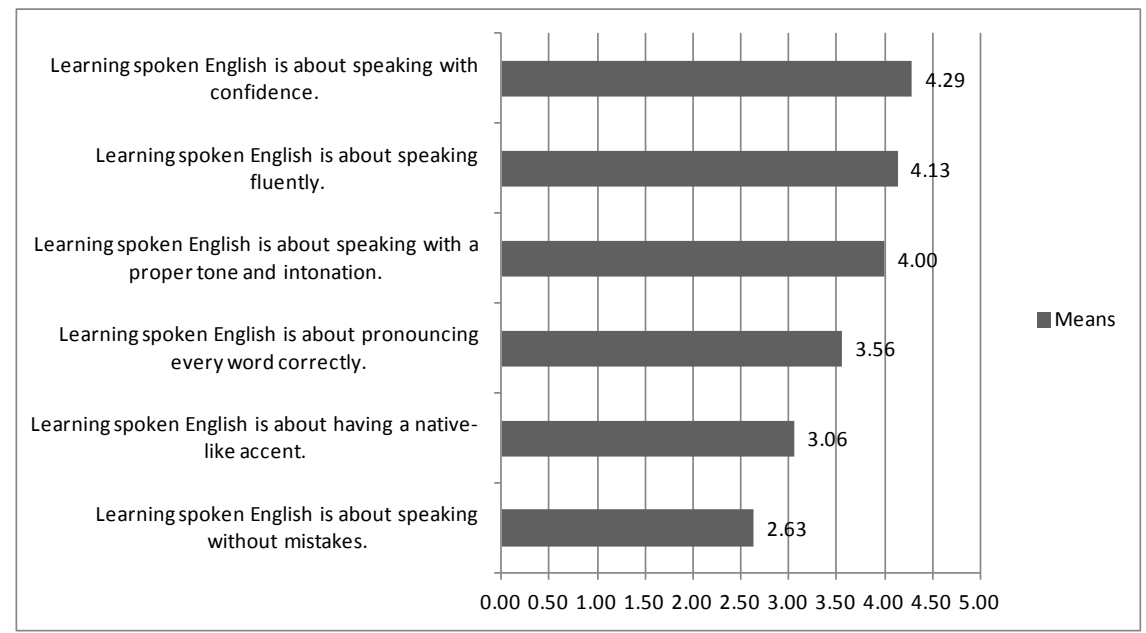

Scale: Strongly Disagree $=1$; Disagree $=2 ;$ Neutral $=3 ;$ Agree $=4$; Strongly Agree $=5$

Figure 7. Attitude towards learning speaking. 
agree that writing is about using as many complex words as possible (2.35); writing in simple English (2.90) and writing fast (2.96). Finally, in the aspect of speaking, subjects tend to agree that learning spoken English is about speaking with confidence (4.29), speaking fluently (4.13) and also speaking with proper tone and intonation. They, however, did not think that learning spoken English is about speaking without mistakes (2.63), and tend to be neutral in thinking that it is about having native-like accent (3.06) and producing every word correctly (3.56).

\subsubsection{Attitude towards Autonomous Learning}

In Part II of the questionnaire, subjects were asked to indicate whether they agree or disagree with some statements concerning their attitude towards autonomous learning (see Figure 8). These statements were adopted from Wenden (1991). Statements with a mean of 3.5 or above include the following: a) "I like using visual aids and modern technologies" (4.19); b) "One important part of learning English is reading about interesting topics" (4.10); c) "I prefer studying English with peers" (i.e. classmates, friends at my age) (3.87); d) "If I had the right materials, I would prefer to spend some time studying alone" (3.85); e) "A big problem in most English classes is that students have different levels" (3.79); f) "Teachers sometimes do not teach what students need to learn" (3.73); g) "I prefer studying English through extra-curricular activities" (3.63); h) "I prefer studying English in a self-access way" (3.5). The two statements with the lowest mean are: a) "Grammar exercises and written homework are not necessary” (2.67) and b) "I prefer studying English at a language lab on my own” (2.96).

\subsubsection{Questionnaire: Open-Ended Questions}

There were five open-ended questions concerning autonomous learning in Part III of the questionnaire concerning self-access learning in secondary education; assessment of own capability of autonomous learning; readiness for autonomous learning; importance of submitting learning evidence and possibility of continuing with selfaccess work in future.

1) Self-access learning in secondary education

When being asked whether the idea of self-access learning was introduced in secondary education, $61.5 \%$ of

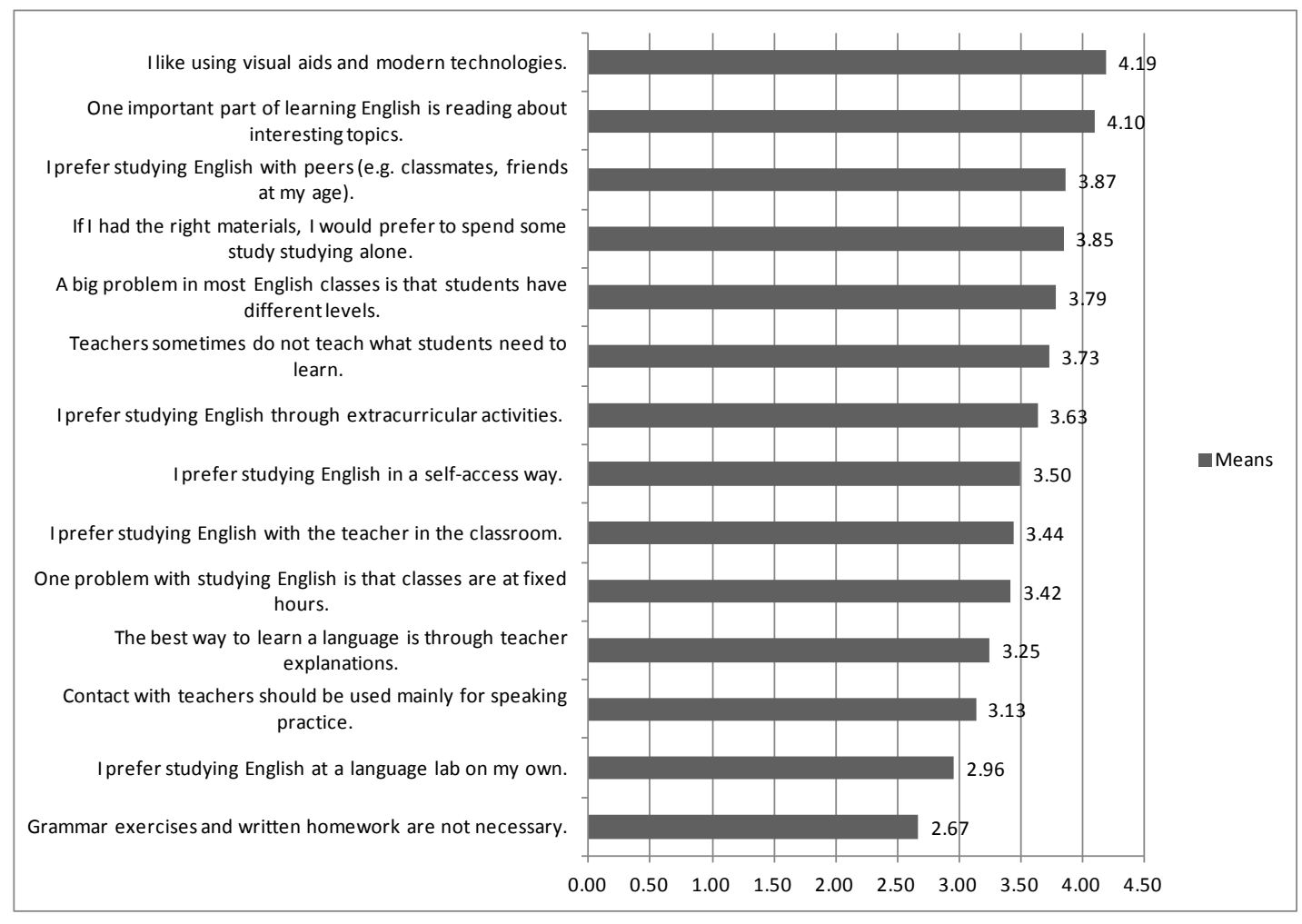

Scale: Strongly Disagree $=1 ;$ Disagree $=2 ;$ Neutral $=3 ;$ Agree $=4$; Strongly Agree $=5$

Figure 8. Attitude towards autonomous learning. 
the subjects (32 out of 52 subjects) expressed that the concept of autonomous learning was introduced in secondary education, while $34.6 \%$ of the subjects (18 out of 52) reported otherwise. 2 of them did not answer this question. 57.7\% (30 out of 52) of the subjects expressed that the idea was introduced by their teachers at school, while only 3 of them said that they attempted autonomous learning on their own. Different sources of autonomous learning were identified. For example, students were introduced to different self-learning materials from daily life, newspapers, magazines, books, novels, blogs and English learning websites. There are also multimedia sources such as movies, music, and radio programmes. They were also encouraged to do both in-class activities (e.g. chatting with foreign peers and speaking English more in class) and outside-class activities (e.g. extracurricular activities and attending relevant seminars and talks). Some teachers also assigned tasks to students in order to monitor their progress. This was in the form of a study plan, specific task assignments, review writing or vocabulary book with new words recorded.

\section{2) Assessment of own capability of autonomous learning}

$69.2 \%$ of the subjects (36 out of 52) believed that they can learn independently through ways like the learning contract. 7.7\% (4 out of 52) of them found autonomous learning difficult. 23.1\% of the subjects (12 subjects) did not answer this question. When being asked whether they could work according to the learning objectives formulated in the learning contract, the subjects identified a number of concerns in autonomous learning, including a) time management; b) the need for setting practical and realistic goals/learning objectives; c) self-discipline; d) motivation; and e) interesting learning topics. There were a few comments claiming that the learning contract assignment is not $100 \%$ autonomous learning as students still need to submit learning evidence and they still have rules to follow. A number of positive comments about the idea were also noted, saying that learning contract is a useful and helpful approach for self-learning and for learning/improving specific language skills.

\section{3) Readiness for autonomous learning}

When being asked if the subjects are ready for autonomous learning and the reasons, $80.8 \%$ of the subjects (42 out of 52 subjects) believed that they are ready while 15.4\% (8 out of 52) of them claimed they are not ready as they need more assistance. 3.9\% (2 of them) said that they are not sure. A number of concerns/comments were suggested by the subjects in order for autonomous learning to take place: a) a need for proper learning materials; b) autonomous learning is significant for tertiary study; c) self-discipline and perseverance; d) assistance from teacher; e) interest in what to learn; f) employing effective ways to self-learn; g) time management; h) personalized learning mode; i) peer support; j) and high flexibility.

\section{4) Importance of submitting learning evidence}

Most subjects (78.8\%, 41 out of 52 subjects) believed that submitting learning evidence helps them fulfill the tasks specified in the learning contract. The main reason was that learning evidence is an effective way of monitoring their learning process, and there is also opportunity for revision and improvement. Some limitations of submitting learning evidence were mentioned, including not knowing what to submit, difficulty of generating evidence for some objectives, and imposing pressure on students.

\section{5) Possibility of continuing doing self-access work for autonomous learning}

The last question asked if subjects would continue doing self-access work to improve their English language proficiency by the end of the course. 61.5\% (31 out of 52 subjects) expressed that they will definitely use learning contract in future for autonomous learning as it is an effective approach for learning in a step-by-step and flexible manner. 13.5\% (7 subjects) indicated that they will do so depending on situations (e.g. time available), while $20 \%$ (13 subjects) said that they will not use learning contract in future as they find it stressful and timeconsuming.

\section{Discussions and Conclusion}

\subsection{Summary of What University Students Do When Given the Opportunity to Self-Learn}

When asked to draft learning objectives in the first semester, there were six areas students worked on, including speaking (86.4\%), vocabulary (47.7\%), writing (45.5\%), listening (34.1\%), reading (20.5\%) and grammar (18.2\%). Even though they were asked to work on grammar only in the second semester, vocabulary still plays a significant role. Among the 57 students who worked on the learning contract in the second semester, there were still $64.9 \%$ of students who worked on vocabulary, followed by writing (14\%) and speaking (3.5\%). As vocabulary is central to reading, writing, listening and speaking, this might be the reason why students find it important to acquire more new vocabulary. Since most students chose speaking/vocabulary and the sample size for others 
choosing other skills was small, inferential statistics examining the correlation between questionnaire findings and the learning objectives formulated by students cannot be done.

From the email messages (see Table 3 for details) sent to the teacher concerning some pressing questions about English learning, the same tendency can be found concerning students' focus on speaking. Most of the questions asked concern speaking, specifically how to speak like a native English speaker (i.e. native accent), use of tone and intonation, fluency and confidence. Questions about vocabulary retention were also common, that is, how to memorize new vocabulary.

No matter what the learning objectives are, it seems that there are two main steps involved in achieving the objectives, i.e. input and output (see Appendices III and IV). The first one is input in the form of joining exhibitions to learn new words, reading newspapers to improve writing and watching English TV dramas/movies to improve listening skill. Output mainly concerns writing and speaking, for example, writing newspaper commentaries and movie reviews, and making presentations, group discussions and reading aloud newspapers. The use of a wide range of receptive and productive means shows the creativity of students and their awareness of what resources are available for autonomous learning. Are university students in Hong Kong ready for autonomous learning?

\subsection{Are University Students Ready for Autonomous Learning?}

The autonomous learning behavior of university students can be supported by the findings of this study in both the learning contract and the questionnaire. The following discusses different aspects indicating the autonomous learning capability of the students, and conclude factors which might impede the potential for autonomy, followed by some suggestions for improvement.

\subsubsection{Dimensions for Autonomous Learning}

Six factors were suggested by Cotterall (1995) in determining whether learners are ready for autonomous learning or not. Though Cotterall also finds it difficult to replicate these factors, findings of this study still shed light into the readiness of university students towards autonomous learning. These factors are a) role of the teacher; b) role of feedback; c) learner independence; d) learner confidence in study ability; e) experience of language learning; and f) approach to studying. In addition to both quantitative and qualitative questionnaire data, the actual learning objectives formulated for the learning contract and email messages for the teacher are all reliable indicators showing students' readiness towards autonomous learning. Below discusses some of the above dimensions with new definitions developed based on the findings.

According to Cotterall (1995), learners who see the teacher's role as dominant do not meet the profile of autonomous learners. In the open-ended questions when being asked if the subjects are ready for autonomous learning, most of them (42 out of 52 subjects, 80.8\%) believed that they are ready. For the few of them who claimed that they are not ready, they asked for more assistance from the teacher (e.g. motivation, enforcement). There were three other statements in Part II of the questionnaire specifically about the role of teachers. The following shows the three statements and the means (with 5 indicating strongly agree and 1 strongly disagree).

- Teachers sometimes do not teach what students need to learn. (3.73)

- I prefer studying English with the teacher in the classroom. (3.44)

- The best way to learn a language is through teacher explanation. (3.25)

Agreeing with the statement that "teachers sometimes do not teach what students need to learn" implies that students know that they could not rely only on the teacher in order to learn.

There were also five statements included in Part I of the questionnaire examining which specific English skill learners need most help from teachers. The following shows the statements and the means (with 5 indicating strongly agree and 1 strongly disagree).

- A lot of listening can be done without a teacher. (4.12)

- A lot of reading can be done without a teacher. (3.85)

- A lot of grammar can be done without a teacher. (3.69)

- A lot of speaking can be done without a teacher. (3.38)

- A lot of writing can be done without a teacher. (2.98)

Findings show that university students in general find themselves autonomous enough though they still need more assistance for writing and speaking. Perhaps this is related to their desire for feedback from the teacher for the two productive skills. 
Table 3. Students' email messages to the teacher.

\begin{tabular}{|c|c|}
\hline 2010-2011 Academic year & Course: ENGL216 English for academic communication \\
\hline Questions/queries in terms of English language learning \\
\hline Speaking \\
\hline
\end{tabular}

- Pronunciation (accents, IPA transcription)

Student 1

I watch quite a lot of English movies and listen to English songs often, and I try to imitate the native English accent but still, it is hard for me to totally get rid of the Hong Kong accent when I speak. What other ways can I further improve my English accent to make my speech sound more native?

Student 2

How can I improve my pronunciation or oral speaking skills?

Student 3

How could I conquer the stage-fright when I have to perform a public speaking in front of the mass?

Student 4

Should I speak very slowly to avoid some bad HK accent and making mistakes?

Student 5

Is British accent more preferable to American accent in Hong Kong? What is the role of "accent” in communication?

(Why do most people feel ashamed if they can't speak/sound like a native English speaker? I believe that accent is just a way to have information about the speaker's background. What's wrong if we have Chinese accent in English when we are Chinese?)

Student 6

What should I do to improve my pronunciation and listening skills?

Student 7

Is it crucial to speak English in an accent?

- $\quad$ Tones, intonation and stress

Student 8

How can I understand the emotional feeling of a speaker well without seeing his/her face impression?

(I know we can decide this from stress and intonation, but it's a little bit difficult.)

- Accuracy

Student 9

How can I improve my fluency and accuracy of speaking?

- $\quad$ Fluency

Student 10

How can I improve my fluency and accuracy of speaking?

Student 11

How can I improve my fluency?

- $\quad$ Language competency (like confidence in giving a speech)

Student 11

I actually believe that my English speaking skill is not bad, but I am always too nervous when

I have to present in front of people, and that makes my speech not fluent. How can I manage to speak more confidently?

Student 12

I would like to know how I can speak English more fluently and confidently.

Student 13

In what ways can I improve my ability to communicate in informal English, in addition to learning formal English from this programme? Should I use simpler words or phrases so that I could think of at the first time, instead of carrying out some paraphrasing in the brain before I speak?

Student 14

How can I seek opportunities to communicate with others in English, whereas my friends are mostly Hong Kongers?

Student 15

I am not confident in giving presentations. Moreover, my grammar is quite poor,

so I need to think twice before giving speeches. This probably reduces my English proficiency.

Student 16

What can be done to improve my English proficiency? I've heard that reading aloud can help, will it help? 


\section{Continued}

Student 17

I know my English is so average and I really don't have much confidence in speaking English in front of so many people (as I think the others are good English speakers). I think this is the largest hurdle for me in this stage.

Student 18

I understand that we have to practise more to improve our English, but it is in fact not that practical to do so in our daily lives as we are living in a Chinese society. So What can I do to gain more opportunities to speak English outside school?

Student 19

I am not the kind of person that afraid of making mistakes. However, I just do not have the courage

to talk in English sometimes. I am not completely comfortable in an "English-speaking environment”.

Student 20

...if I want to talk fluently, I must make many grammatical mistakes. Yet, if I want to reduce those mistakes, I need plenty of time to think and organise what I am going to say. So how can I manage them at the same time?

Student 21

How can I be more confident when I'm speaking English?

- The ability to achieve a specific goal (like presentation)/information delivery

Student 22

How I can make funny, interactive and informative presentations? How can I upgrade my presentation skills?

Student 23

How to improve my body gesture when I am giving speech?

Student 24

In most courses, students are required to do presentations, but my public speaking skills are relatively weak.

I would like to know how can I give an impressive speech?

Student 25

Since I am taking the CBS programmes, I am worrying if there is a great depress in my English proficiency as I am taught in Cantonese and Mandarin most of time.

Student 26

How can I reply the questions well in the Q\&A section after the presentation?

(As the Q \& A section has no time to organize. I hope to know the skills to do better.)

Student 27

In the aspect of speaking, I would like to learn how I catch the attention of audience.

\section{Listening}

- $\quad$ Listening comprehension

Student 28

How can I be able to grasp the main points of the speaker when he/she is speaking very fast? I am weak at listening, especially when dealing with foreigners. What are some long lasting methods I can use to improve my listening?

Student 29

Another difficulty I encounter is that I find it difficult to understand someone's English with special accent.

Therefore, I tried to talk to foreign classmates more often and I hope I can overcome this difficulty.

Student 30

Sometimes I even can not determine what the main idea of the speaker is. In the future, I may not be able to attend meetings effectively as I fail to jot down key points of the speaker. How can I improve that?

Student 31

How can I understand the humors from native speakers easily? (As this is a communication class, I think understanding what the speaker said is very important. If I can understand the native speaker's humors, the conversation will be happier and smoother.)

\section{- $\quad$ Note-taking skills}

\section{Student 32}

How can I develop good listening skills? As far as I know, it is uneasy, if not difficult, for me to jot careful notes during listening tests. Simply, I can't score good grades in such listening tests.

Student 33

The second difficulty for me is that I can never effectively jot notes during listening (this is my weakest paper in F.7).

It makes me hard to catch the main point of the speaker when I am writing too slow.

- An overall improvement in listening skills 


\section{Continued}

Student 34

....is it beneficial to my listening skill if I keep watching the drama series which is easier to listen to their conversation? Or should I watch the Hollywood films which background music or sound effects are louder in the throes of practising my listening skills?

Student 35

What should I do to improve my pronunciation and listening skills?

Student 36

From my experience, the biggest difficulty of learning English is spelling and listening. Hence,

I really want to know how to improve these two parts.

\section{Writing}

- The capacity to fulfill a specific writing task

Student 37

How can I improve my writing styles and know more sentence structures?

Student 38

And for the writing skills, as I have mentioned before, I want to write in a more native and natural way.

Do you have any recommendations for me to read?

Student 39

I sincerely want to improve it through learning different sentence structures, collocations, arguments etc. In specific, I want to learn to write in a journalistic style, like those editorials in newspaper. What should I read and pay attention to in order to achieve my aim?

Student 40

My question is, which one would you choose, start a podcast or start a blog?

Student 41

I'd love to grasp more knowledge and techniques about how to write a piece of grammatically

correct and meanwhile well-presented article.

\section{Reading}

- $\quad$ Reading comprehension

Student 42

Another one is the cultural difference in language. I know the individual word in a sentence but still I cannot figure out what it means. It is really frustrating.

- Effectiveness and efficiency of reading (like skim and scanning skills)

Student 43

Sometimes my reading speed is rather slow so I would like to know how I can improve my reading speed.

Student 44

How can I read a bit faster?

Student 45

Should I look up every unfamiliar word in the dictionary when reading?

- Reading habits cultivation

Student 46

Should I keep on reading more English books? Should 1 read some novels or some academic essays (must be boring)? What should l do if I have not much time for reading?

\section{Vocabulary}

- Expansion of the quantity of the vocabularies

Student 47

1. I always want to learn more new vocabularies so I try to read more English books, but I feel that

it is impossible to remember all new words that I come across when I am reading a book.

Should I really check every single vocabulary that I do not know on dictionaries once I come across it?

Student 48

Not only formal and academic English, I'm also interested in learning informal English,

for example, idioms and slang. I would like to know by what means can I learn these items?

Student 49

What should I do if I want to know more about the usage of a new word as sometimes we can't learn it from a dictionary? 


\section{Continued}

- Active use of the vocabulary knowledge in different aspects

Student 50

I always read newspaper to improve my English. Whenever I encounter new word, I will jot it down. However,

I can only use few of them in composition. How can I memorize those new words more efficiently?

- Memorization of newly-learned vocabularies

Student 51

Is there an effective way to remember vocabulary, if yes, how?

- Idioms and slangs

\section{Grammar}

- Avoid spelling mistakes

Student 52

From my experience, the biggest difficulty of learning English is spelling and listening.

Hence, I really want to know how to improve these two parts.

Student 53

The biggest problem I face when I'm learning English is that I can't memorize grammar rules, I forget them soon after I learn them, so is there any method that could help me memorizing grammar? or should I try to understand the underlying principle instead of just recite them?

\section{Application of language skills}

- Application of language learning from a career perspective

Student 54

What subjects or what direction should I go to help me to be an English teacher in the future?

(I want to be an English teacher in the future.)

- Acquisition of other foreign languages

Student 55

... my question is do you think mastering English would allow me to pick up other languages

(e.g., Spanish, French) more easily? I am really interested in language study.

\section{Seek for an alternative of the learning habit}

\section{Student 56}

I just want to find a way which is not doing grammar exercises yet can improve my grammar.

Is it that hard? Is doing exercise the only way?

Student 57

....my question is, are there any more ways to be familiar with the usage of grammar, other than buying a grammar exercise and chew on it?

Learner independence is defined as having "clearly-defined goals and to be comfortable experimenting with new activities" (Cotterall, 1995: p. 199). This is actually characteristics of good language learners suggested by Ellis and Sinclair (1989) about willing to experiment. It can be seen that in order to be an autonomous learner, the learner himself or herself is central instead of the teacher. In Part II of the questionnaire, two statements are of most relevant:

- I prefer studying English through extra-curricular activities. (3.63)

- I prefer studying English in a self-access way. (3.50)

Having a mean of over 3.5 shows that the subjects prefer studying in a self-access way and they like experimenting different ways in doing self-access work.

In the open-ended questions, the subjects also expressed that it is important to have clear, practical and realistic language learning goals. Some of the quotes are listed as follows:

- "The goal set at the beginning usually too high to achieve. After the first experience in doing learning contracts, second time I set some realistic goal. And finally I achieve all the goals.” (No. 34)

- "I consider myself capable of learning English through ways like learning contract as I am able to reach my objectives stated in the learning contract by doing different kinds of self-access work.” (No. 8) 
The variety of measures used by the students in the learning contract also shows their willingness to attempt, and thus demonstrate learner independence.

It was argued in Cotterall (1995: p. 202) that learners who have been successful in language learning have their own ways of testing how much they have learned, and have a high degree of awareness about themselves, about language learning and strategies: "Autonomous learners use their experience of attempting tasks, employing strategies and solving problems to develop their understanding of how language learning works." In this study, all the subjects can be regarded as successful language learners as many of them received grade B or above in the Advanced Level English Examination (HKAL) before being admitted. In addition to being successful in language learning, what is more important might be their actual experience of English learning and self-access experience. Many of the subjects reported that they studied in English medium (EMI) secondary schools in Hong Kong which provided them with an English-speaking environment and much experience of involving in English-speaking activities (e.g. English team, Drama club, English enhancement programmes, inter-school English drama competition). In the open-ended question, $61.5 \%$ of the subjects said that the concept of autonomous learning was introduced in their secondary education (and even primary education), and there were different ways introduced by their teacher for self-learning, which might have played a significant role in paving the way for learners to understand that autonomous learning is important and teacher is not the only source for effective language learning:

- "Yes, I have been learning independently since primary school. Teachers encouraged us to read books, watch movies, using online materials, etc. all help develops myself to learn independently.” (No. 40)

- "As a university student, it is impossible to find a teacher whenever I encounter difficulties. Instead, it would be more efficient when I attempt to solve the problems myself first, and turn to others for help when I really cannot cope with it myself." (No. 19)

When asked in the open-ended questions whether the subjects consider themselves capable of learning English through ways like learning contract and whether they will continue with self-access work, the answers are generally positive. Being competent in doing self-access work and being confident of doing so are both important. It is encouraging that there are indicators in this study showing a tendency of autonomous learning, and at the same time, learners also recognize the importance of monitoring the self-learning process using learning contract, which demonstrates what Breen and Mann called a "a robust sense of self” (1997, p. 134).

\subsubsection{Factors Impeding the Potential for Autonomy and Suggestions for Improvement}

A number of factors were identified in the literature as obstacles or challenges of implementing autonomous learning, which involve the learner, the teacher and also the institution/policy maker. In addition to the motivation and willingness of the learner to self-learn, the teacher's level of autonomy and expectations of students, and constraints imposed by the institution, this study also suggests other factors and considerations which might impede the potential for autonomy. Below summarizes these concerns and possible ways to deal with the challenges.

One key factor which can determine whether effective autonomous learning can take place is the language learning attitude as reflected from the learning contract assignment and questionnaire findings about specific language learning beliefs of the subjects. As discussed in 5.1, speaking and vocabulary are the two major areas the subjects find important, and a variety of means were used to address them. In Part II of the questionnaire, the subjects were asked to tell their attitude towards listening, reading, writing and speaking. It was found that students in general have "correct" language beliefs and know what the four skills are and are not about. For example, they understand that listening is not about understanding every word in English, and so is reading. Incorrect language learning beliefs are detrimental as they can lead to not only poor language learning outcome as the literature review shows, but determine whether autonomous learning is effective or not. For example, if believing that writing is all about using as many complex words as possible, much attention would be spent on memorizing difficult words and using such words in writing, which might not be too meaningful in facilitating language learning. Autonomous learning should never mean learning without the presence of teachers. Teachers' appropriate and timely guidance and feedback for students at the stage of formulating learning objectives is therefore of great importance.

Time management is another main concern of some students who expressed that they find it difficult to carry out the tasks stipulated in the learning contract because of time constraint and poor time management skill. When this learning contract assignment was introduced twelve years ago with the year one students, they were 
asked by the teacher to submit learning evidence only once at the end of the semester. The outcome was that students only started working on the self-access work when the deadline was approaching. Changes have been introduced since to help monitor students' progress, including a) an in-class discussion in class (requiring them to share with peers what they have done in the middle of the semester, the difficulties encountered and possible changes to be made); b) a reflective essay plus c) a semester-end presentation allowing students to spell out their autonomous work and improvement; and the new requirement of submitting evidence for three times in the course of the semester encouraging students to do self-access work regularly. These measures seem to be appreciated and well-received as seen from the following students' comments:

- "Yes, I would not have followed the tasks stated in the learning contract is there is no need for me to submit the learning evidence." (No. 4)

- "Yes, although I think I have control over myself, I can better force myself to do if I have to submit the learning evidence.” (No. 7)

- "Submitting learning evidence helps me fulfilling the tasks. It is because university life is busy and I would spend much time entertaining. Learning contract gives me a drive or a kind of force for me to keep on schedule.” (No. 15)

- "Yes, I can actually monitor the progress of my study. If we don't have to submit learning evidence, I will be very lazy to follow the plan.” (No. 17)

Though teachers' role should not be dominant in autonomous learning, timely guidance and feedback at the initial stage of formulating learning objectives, interim review, and end-of-semester feedback for students are deemed necessary.

This study is significant in examining the language learning beliefs of the language students of one university in Hong Kong when given the opportunity to self-learn. Results show that these students are ready for autonomous learning and they welcome the idea of learning contract in motivating them and monitoring their progress. This does not come easy as the idea of autonomous learning was actually introduced early in secondary education to prepare students for lifelong learning. Among the three factors which might impede the implementation of language autonomy suggested by Borg (2011), one of them, i.e. the learner factor, is well dealt with in this study. Two other factors, including the teacher factor and the institutional factor might be topics for examination in future studies. The sample size of this study could be larger; to better represent university students in Hong Kong, more university students not of language majors could be included in future studies. A comparison of students in Hong Kong and other Asian countries can also help develop a profile of language learning autonomy for Asian students.

\section{References}

Banya, K., \& Cheng, M. H. (1997). Beliefs about Foreign Language Learning-A Study of Beliefs of Teachers’ and Students’ Cross Cultural Settings. 31st Annual Meeting of the Teachers of Speakers of Other Languages, Florida.

Benson, P. (2000). “Autonomy as a Learners’ and Teacher’s Right”. In B. Sinclair, I. Mcgrath, \& T. Lamb (Eds.), Learner Autonomy, Teacher Autonomy: New Directions (pp. 111-117). London: Addison Wesley Longman.

Benson, P. (2001). Teaching and Researching Autonomy in Language Learning. New York, NY: Longman/Pearson Education.

Borg, S. (2011). Language Teacher Education. In J. Simpson (Eds.) The Routledge Handbook of Applied Linguistics (pp. 215-228). London: Routledge.

Breen, M. P., \& Mann, S. J. (1997). Shooting Arrows at the Sun: Perspectives on a Pedagogy for Autonomy' in Benson and Voller. In P. Benson, \& P. Voller (Eds.), Autonomy and Independence in Language Learning (pp. 132-149). London: Longman.

Brown, H. D. (1994). Principles of Language Learning and Teaching. Upper Saddle River, NJ: Prentice Hall.

Cotterall, S. (1995). Readiness for Autonomy: Investigating Learner Beliefs. System, 23, 195-205.

Cotterall, S. (1999). Key Variables in Language Learning: What Do Learners Believe about Them? System, 27, 493-513.

Davies, A. (2003). Teachers' and Students’ Beliefs Regarding Aspects of Language Learning. Evaluation and Research in Education, 17, 207-222.

Educational Bureau (EDB) (2013). The Use of Self-Evaluation in Promoting Good Practice within the Scheme. http://www.edb.gov.hk/attachment/en/curriculum-development/resource-support/net/networking_good\%20practice_part\% 203.pdf 
Ellis, G., \& Sinclair, B. (1989). Learning to Learn. Cambridge: Cambridge University Press.

Ellis, N. C. (2008). The Dynamics of Second Language Emergence: Cycles of Language Use, Language Change, and Language Acquisition. Modern Language Journal, 92, 232-249.

Eslami-Rasekh, Z., \& Valizadeh, K. (2004). Classroom Activities Viewed from Different Perspectives: Learners’ Voice vs. Teachers' Voice. TESL EJ, 8, 1-13. http://tesl-ej.org/ej31/a2.html

Gui, D. A., \& Northen, A. (2013). Supplementing self-access learning for an English Language Centre through virtual platforms.' Retrieved http://www.inter-disciplinary.net/at-the-interface/wp-content/uploads/2013/02/DeanGui_dpaper_elvw3.pdf

Hawkey, T. (2006). Teacher and Learner Perception of Language Learning Activity. ELT Journal, 60, 242-252.

Holec, H. (1981). Autonomy and Foreign Language Learning. Oxford/New York: Pergamon Press. (First Published 1979, Council of Europe).

Horwitz, E. K. (1988). The Beliefs about Language Learning of Beginning University Foreign Language Students. The Modern Language Journal, 72, 283-294.

Kern, R. G. (1995). Students’ and Teachers’ Beliefs about Language Learning. Foreign Language Annals, 28, 71-92.

Littlewood, W. (1991). Curriculum Design. In R. Bowers, \& C. J. Brumfit (Eds.), Applied Linguistics and Language Teaching (pp. 11-22). London: Macmillan \& The British Council.

Littlewood, W. (1999). Defining and Developing Autonomy in East Asian Contexts. Applied Linguistics, 20, 71-94.

Miller, L., Hopkins, M., \& Tsang, E. (2007). Establishing a Self-Access Centre in a Secondary School. English Language Teaching Journal, 61, 220-227.

Nunan, D. (1997). Designing and Adapting Materials to Encourage Learner Autonomy. In P. Benson, \& P. Voller (Eds.). Autonomy and Independence in Language Learning (pp. 192-203). London: Longman.

Oslund, J., Kolb, D., Rubin, I., \& Turner, M. (2001). Organizational Behavior: An Experiential Approach. Upper Saddle River, NJ: Prentice Hall.

Oxford, R. L. (1990). Language Learning Strategies. Boston: Heinle \& Heinle Publisher.

Peacock, M. (1999). Beliefs about Language Learning and Their Relationship to Proficiency. International Journal of Applied Linguistics, 9, 247-263.

Rubin, J. (1975). What the “Good Language Learner” Can Teach Us. TESOL Quarterly, 9, 41-51.

Rubin, J. (1981). Study of Cognitive Processes in Second Language Learning. Applied Linguistics, 11, 117-123.

Rubin, J., \& Thompson, I. (1982). How to Be a More Successful Language Learner. Boston, Mass.: Heinle \& Heinle Publishers.

Siebert, D. C., Wilke, D. J., Delva, J., Smith, M. P., \& Howell, R. L. (2003). Differences in African American and White College Students' Drinking Behaviors: Consequences, Harm Reduction Strategies, and Health Information Sources. Journal of American College Health, 52, 123-129.

Wenden, A. (1991). Learner Strategies for Learner Autonomy. Upper Saddle River, NJ: Prentice Hall.

Yang, N. D. (1999). The Relationship between EFL Learners’ Beliefs and Learning Strategy Use. System, 27, 515-535. 


\section{Appendix I: Sample Questionnaire}

This questionnaire is designed to provide information regarding university students' belief about language learning and their readiness for learning autonomously. The information you provide will enable the PolyU to better understand the possible differences between learning needs of students at tertiary level and the instructors' perceptions of these needs. All data collected will be treated in the strictest confidence.

\section{Personal information}

Please indicate your personal information as follows:

1. Name:

2. Student ID:

3. Age:

4. Gender: Female ( ) Male ( )

5. The programme you are studying in: BAESP ( ) BACBS ( ) Others, please specify

6. E-mail address:

\section{I.1. Part I}

This part is about your beliefs and attitudes towards language learning and specific learning objectives. Please answer each item by circling the number (from 1 to 5 ) in the boxes representing your extent of agreement with the statements and fill in incomplete sentences to show your beliefs towards different skills (i.e. listening, reading, writing, speaking).

\begin{tabular}{|c|c|c|c|c|c|c|}
\hline \multicolumn{7}{|c|}{ Beliefs and attitudes towards learning } \\
\hline 1 & A lot of grammar can be done without a teacher. & $\begin{array}{c}\text { Strongly } \\
\text { agree } \\
5\end{array}$ & $\begin{array}{c}\text { Agree } \\
4\end{array}$ & $\begin{array}{c}\text { Neutral } \\
3\end{array}$ & $\begin{array}{l}\text { Disagree } \\
2\end{array}$ & $\begin{array}{c}\text { Strongly } \\
\text { disagree } \\
1\end{array}$ \\
\hline 2 & A lot of listening can be done without a teacher. & $\begin{array}{l}\text { Strongly } \\
\text { agree } \\
5\end{array}$ & $\begin{array}{c}\text { Agree } \\
4\end{array}$ & $\begin{array}{l}\text { Neutral } \\
3\end{array}$ & $\begin{array}{l}\text { Disagree } \\
2\end{array}$ & $\begin{array}{l}\text { Strongly } \\
\text { disagree } \\
1\end{array}$ \\
\hline 3 & A lot of reading can be done without a teacher. & $\begin{array}{l}\text { Strongly } \\
\text { agree } \\
5\end{array}$ & $\begin{array}{l}\text { Agree } \\
4\end{array}$ & $\begin{array}{l}\text { Neutral } \\
3\end{array}$ & $\begin{array}{l}\text { Disagree } \\
2\end{array}$ & $\begin{array}{l}\text { Strongly } \\
\text { disagree } \\
\quad 1\end{array}$ \\
\hline 4 & A lot of writing can be done without a teacher. & $\begin{array}{l}\text { Strongly } \\
\text { agree } \\
5\end{array}$ & $\begin{array}{c}\text { Agree } \\
4\end{array}$ & $\begin{array}{l}\text { Neutral } \\
3\end{array}$ & $\begin{array}{l}\text { Disagree } \\
\quad 2\end{array}$ & $\begin{array}{l}\text { Strongly } \\
\text { disagree } \\
1\end{array}$ \\
\hline 5 & A lot of speaking can be done without a teacher. & $\begin{array}{l}\text { Strongly } \\
\text { agree } \\
5\end{array}$ & $\begin{array}{l}\text { Agree } \\
4\end{array}$ & $\begin{array}{l}\text { Neutral } \\
3\end{array}$ & $\begin{array}{l}\text { Disagree } \\
2\end{array}$ & $\begin{array}{l}\text { Strongly } \\
\text { disagree } \\
\quad 1\end{array}$ \\
\hline 6 & I prefer to study with people who are eager to learn English. & $\begin{array}{l}\text { Strongly } \\
\text { agree } \\
5\end{array}$ & $\begin{array}{c}\text { Agree } \\
4\end{array}$ & $\begin{array}{l}\text { Neutral } \\
3\end{array}$ & $\begin{array}{l}\text { Disagree } \\
2\end{array}$ & $\begin{array}{l}\text { Strongly } \\
\text { disagree } \\
1\end{array}$ \\
\hline 7 & $\begin{array}{l}\text { Some people are born with a special ability } \\
\text { which helps them learn a foreign language. }\end{array}$ & $\begin{array}{c}\text { Strongly } \\
\text { agree } \\
5\end{array}$ & $\begin{array}{c}\text { Agree } \\
4\end{array}$ & $\begin{array}{c}\text { Neutral } \\
3\end{array}$ & $\begin{array}{l}\text { Disagree } \\
2\end{array}$ & $\begin{array}{c}\text { Strongly } \\
\text { disagree } \\
1\end{array}$ \\
\hline 8 & It is important to speak a foreign language with an excellent accent. & $\begin{array}{c}\text { Strongly } \\
\text { agree } \\
5\end{array}$ & $\begin{array}{l}\text { Agree } \\
4\end{array}$ & $\begin{array}{l}\text { Neutral } \\
3\end{array}$ & $\begin{array}{l}\text { Disagree } \\
2\end{array}$ & $\begin{array}{c}\text { Strongly } \\
\text { disagree } \\
1\end{array}$ \\
\hline 9 & $\begin{array}{l}\text { You shouldn't say anything in the foreign language } \\
\text { until you can say it correctly. }\end{array}$ & $\begin{array}{c}\text { Strongly } \\
\text { agree } \\
5\end{array}$ & $\begin{array}{l}\text { Agree } \\
4\end{array}$ & $\begin{array}{l}\text { Neutral } \\
3\end{array}$ & $\begin{array}{l}\text { Disagree } \\
2\end{array}$ & $\begin{array}{c}\text { Strongly } \\
\text { disagree } \\
1\end{array}$ \\
\hline 10 & $\begin{array}{l}\text { If someone spent one hour a day learning a language, how long } \\
\text { would it take him/her to become fluent? 1) less than a year, } \\
\text { 2) } 1-2 \text { years, 3) } 3-5 \text { years, 4) } 5-10 \text { years, } \\
\text { 5) You can't learn a language in } 1 \text { hour a day. }\end{array}$ & $\begin{array}{l}\text { Strongly } \\
\text { agree } \\
5\end{array}$ & $\begin{array}{c}\text { Agree } \\
4\end{array}$ & $\begin{array}{c}\text { Neutral } \\
3\end{array}$ & $\begin{array}{c}\text { Disagree } \\
2\end{array}$ & $\begin{array}{c}\text { Strongly } \\
\text { disagree } \\
1\end{array}$ \\
\hline 11 & I have foreign language aptitude (talents). & $\begin{array}{l}\text { Strongly } \\
\text { agree } \\
5\end{array}$ & $\begin{array}{c}\text { Agree } \\
4\end{array}$ & $\begin{array}{c}\text { Neutral } \\
3\end{array}$ & $\begin{array}{c}\text { Disagree } \\
2\end{array}$ & $\begin{array}{c}\text { Strongly } \\
\text { disagree } \\
1\end{array}$ \\
\hline
\end{tabular}




\section{Continued}

12

14 It is important to practise in the language laboratory.

15 Hong Kong Chinese are good at learning foreign languages.

\section{Attitudes towards specific language objectives}

\section{Listening}

17

Learning listening skills is about understanding every word said in English.

18

19

20

21

22

23

Learning listening skills is about getting the main idea of what others said in English.

Learning listening skills is about being able to summarize what others have said.

Learning listening skills is about being able to understand what are taught in class.

Learning listening skills is about

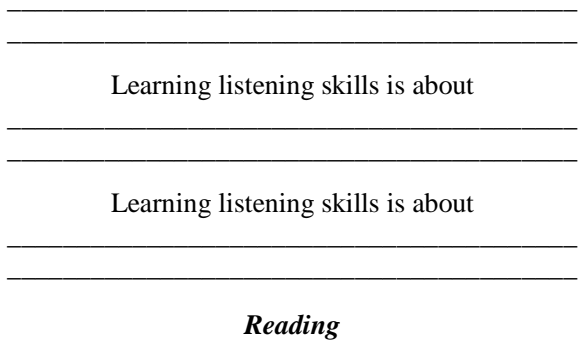

24

Learning reading skills is about understanding every word of a text in English.

25

26

Learning reading skills is about reading fast.

27

Learning reading skills is about skimming and scanning.

28

Learning reading skills is about understanding academic articles.
Strongly

agre$$
5
$$

Agree

Neutral

Disagree

2

Strongly

disagree

Strongly
agree

agree
5

Agr

gree
4

Neutral

Disagree

1

Strongly

agree

Agr

gree

3

2

Strongly

disagree

1

Strongly

disagree

1

Strongly

disagree

Strongly

agree
5

Agr
4

Neutral

Disagree

2

Strongly

agree

Agr

4 Neutral

Disagree 1

Strongly disagree

1

\begin{tabular}{|c|c|c|c|c|}
\hline $\begin{array}{l}\text { Strongly } \\
\text { agree } \\
5\end{array}$ & $\begin{array}{c}\text { Agree } \\
4\end{array}$ & $\begin{array}{c}\text { Neutral } \\
3\end{array}$ & $\begin{array}{c}\text { Disagree } \\
2\end{array}$ & $\begin{array}{c}\text { Strongly } \\
\text { disagree } \\
1\end{array}$ \\
\hline $\begin{array}{l}\text { Strongly } \\
\text { agree } \\
5\end{array}$ & $\begin{array}{c}\text { Agree } \\
4\end{array}$ & $\begin{array}{c}\text { Neutral } \\
3\end{array}$ & $\begin{array}{c}\text { Disagree } \\
2\end{array}$ & $\begin{array}{c}\text { Strongly } \\
\text { disagree } \\
1\end{array}$ \\
\hline $\begin{array}{l}\text { Strongly } \\
\text { agree } \\
5\end{array}$ & $\begin{array}{c}\text { Agree } \\
4\end{array}$ & $\begin{array}{c}\text { Neutral } \\
3\end{array}$ & $\begin{array}{c}\text { Disagree } \\
2\end{array}$ & $\begin{array}{c}\text { Strongly } \\
\text { disagree } \\
1\end{array}$ \\
\hline $\begin{array}{l}\text { Strongly } \\
\text { agree } \\
5\end{array}$ & $\begin{array}{c}\text { Agree } \\
4\end{array}$ & $\begin{array}{c}\text { Neutral } \\
3\end{array}$ & $\begin{array}{c}\text { Disagree } \\
2\end{array}$ & $\begin{array}{c}\text { Strongly } \\
\text { disagree } \\
1\end{array}$ \\
\hline $\begin{array}{l}\text { Strongly } \\
\text { agree } \\
5\end{array}$ & $\begin{array}{c}\text { Agree } \\
4\end{array}$ & $\begin{array}{c}\text { Neutral } \\
3\end{array}$ & $\begin{array}{c}\text { Disagree } \\
2\end{array}$ & $\begin{array}{c}\text { Strongly } \\
\text { disagree } \\
1\end{array}$ \\
\hline $\begin{array}{l}\text { Strongly } \\
\text { agree } \\
5\end{array}$ & $\begin{array}{c}\text { Agree } \\
4\end{array}$ & $\begin{array}{c}\text { Neutral } \\
3\end{array}$ & $\begin{array}{c}\text { Disagree } \\
2\end{array}$ & $\begin{array}{c}\text { Strongly } \\
\text { disagree } \\
1\end{array}$ \\
\hline $\begin{array}{l}\text { Strongly } \\
\text { agree } \\
5\end{array}$ & $\begin{array}{c}\text { Agree } \\
4\end{array}$ & $\begin{array}{c}\text { Neutral } \\
3\end{array}$ & $\begin{array}{c}\text { Disagree } \\
2\end{array}$ & $\begin{array}{c}\text { Strongly } \\
\text { disagree } \\
1\end{array}$ \\
\hline $\begin{array}{l}\text { Strongly } \\
\text { agree } \\
5\end{array}$ & $\begin{array}{c}\text { Agree } \\
4\end{array}$ & $\begin{array}{c}\text { Neutral } \\
3\end{array}$ & $\begin{array}{c}\text { Disagree } \\
2\end{array}$ & $\begin{array}{c}\text { Strongly } \\
\text { disagree } \\
1\end{array}$ \\
\hline $\begin{array}{l}\text { Strongly } \\
\text { agree } \\
5\end{array}$ & $\begin{array}{c}\text { Agree } \\
4\end{array}$ & $\begin{array}{c}\text { Neutral } \\
3\end{array}$ & $\begin{array}{c}\text { Disagree } \\
2\end{array}$ & $\begin{array}{c}\text { Strongly } \\
\text { disagree } \\
1\end{array}$ \\
\hline $\begin{array}{l}\text { Strongly } \\
\text { agree } \\
5\end{array}$ & $\begin{array}{c}\text { Agree } \\
4\end{array}$ & $\begin{array}{c}\text { Neutral } \\
3\end{array}$ & $\begin{array}{c}\text { Disagree } \\
2\end{array}$ & $\begin{array}{c}\text { Strongly } \\
\text { disagree } \\
1\end{array}$ \\
\hline $\begin{array}{l}\text { Strongly } \\
\text { agree } \\
5\end{array}$ & $\begin{array}{c}\text { Agree } \\
4\end{array}$ & $\begin{array}{c}\text { Neutral } \\
3\end{array}$ & $\begin{array}{c}\text { Disagree } \\
2\end{array}$ & $\begin{array}{c}\text { Strongly } \\
\text { disagree } \\
1\end{array}$ \\
\hline $\begin{array}{l}\text { Strongly } \\
\text { agree } \\
5\end{array}$ & $\begin{array}{c}\text { Agree } \\
4\end{array}$ & $\begin{array}{c}\text { Neutral } \\
3\end{array}$ & $\begin{array}{c}\text { Disagree } \\
2\end{array}$ & $\begin{array}{l}\text { Strongly } \\
\text { disagree }\end{array}$ \\
\hline
\end{tabular}

5 1 


\section{Continued}

30

31

\begin{tabular}{c}
\hline Learning reading skills is about \\
\hline Learning reading skills is about \\
\hline Learning reading skills is about
\end{tabular}

Writing

32

Learning English writing is about using as many complex words as possible.

33

34

Learning English writing is about using correct grammar.

35

Learning English writing is about being able to write long passages.

36

Learning English writing is about appropriate use of words.

37

38

39

40 Learning English writing is about being able to write concisely.

41

42

43

44
Learning English writing is about being aware of different writing styles and formats.

Learning English writing is about

Speaking

Learning English writing is about the use of various sentence patterns.

Learning English writing is about writing fast.

Learning English writing is about

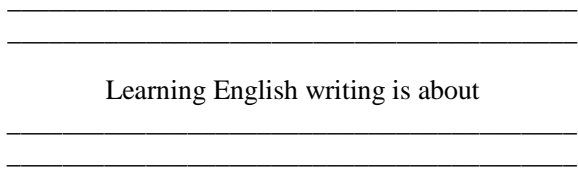

\begin{tabular}{|c|c|c|c|c|}
\hline $\begin{array}{c}\text { Strongly } \\
\text { agree } \\
5\end{array}$ & $\begin{array}{c}\text { Agree } \\
4\end{array}$ & $\begin{array}{c}\text { Neutral } \\
3\end{array}$ & $\begin{array}{c}\text { Disagree } \\
2\end{array}$ & $\begin{array}{c}\text { Strongly } \\
\text { disagree } \\
1\end{array}$ \\
\hline $\begin{array}{l}\text { Strongly } \\
\text { agree } \\
5\end{array}$ & $\begin{array}{c}\text { Agree } \\
4\end{array}$ & $\begin{array}{c}\text { Neutral } \\
3\end{array}$ & $\begin{array}{c}\text { Disagree } \\
2\end{array}$ & $\begin{array}{c}\text { Strongly } \\
\text { disagree } \\
1\end{array}$ \\
\hline $\begin{array}{c}\text { Strongly } \\
\text { agree } \\
5\end{array}$ & $\begin{array}{c}\text { Agree } \\
4\end{array}$ & $\begin{array}{c}\text { Neutral } \\
3\end{array}$ & $\begin{array}{c}\text { Disagree } \\
2\end{array}$ & $\begin{array}{c}\text { Strongly } \\
\text { disagree }\end{array}$ \\
\hline
\end{tabular}

Strongly

agre

5

\section{Ag}

Neutra

Strongly

agree
5

Ag

Strongly

agree

5

Strongly

agree
5

Strongly

agree
5

trongly

agree

5

Strongly

agree
5

Strongly

agree

5

Strongly

agree

5

Strongly

agree
5

trongly

agree

5

Strongly

agree
5

Strongly

agree
5

\section{Ag}

4

Agr

4

Ag

4

Agr

4

Ag

$$
\begin{gathered}
\text { Agree } \\
4
\end{gathered}
$$

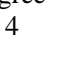

Ne

$$
\begin{gathered}
\text { Neutra } \\
3
\end{gathered}
$$

3

\section{Agr}

$$
4
$$

Ne

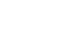

Ag

4

Ne

Neutra
3

(1)

D

gree

4
4

4

Neu

utral

3

.

Agr
4

4

Neu

$$
3
$$

Ag

Agr
4

Ne

Neut

3

Disagree

2

isagree

2

Disagree

2

Disagree

2

Disagree

2

Disagree

2

Disagree

2

Disagree

2

Disagree

2

Disagree

2

Strongly

disagree

1

Strongly

disagree

1

45 Learning spoken English is about having a native-like accent.

Strongly

agree

\section{Agree Neutral Disagree \\ 2}

Strongly

disagree 


\section{Continued}

\begin{tabular}{|c|c|c|c|c|c|c|}
\hline 46 & Learning spoken English is about pronouncing every word correctly. & $\begin{array}{c}\text { Strongly } \\
\text { agree } \\
5\end{array}$ & $\begin{array}{l}\text { Agree } \\
4\end{array}$ & $\begin{array}{l}\text { Neutral } \\
3\end{array}$ & $\begin{array}{l}\text { Disagree } \\
2\end{array}$ & $\begin{array}{c}\text { Strongly } \\
\text { disagree } \\
1\end{array}$ \\
\hline 47 & $\begin{array}{l}\text { Learning spoken English is about speaking } \\
\text { with a proper tone and intonation. }\end{array}$ & $\begin{array}{c}\text { Strongly } \\
\text { agree } \\
5\end{array}$ & $\begin{array}{c}\text { Agree } \\
4\end{array}$ & $\begin{array}{l}\text { Neutral } \\
3\end{array}$ & $\begin{array}{l}\text { Disagree } \\
2\end{array}$ & $\begin{array}{c}\text { Strongly } \\
\text { disagree } \\
1\end{array}$ \\
\hline 48 & Learning spoken English is about speaking fluently. & $\begin{array}{c}\text { Strongly } \\
\text { agree } \\
5\end{array}$ & $\begin{array}{l}\text { Agree } \\
4\end{array}$ & $\begin{array}{c}\text { Neutral } \\
3\end{array}$ & $\begin{array}{l}\text { Disagree } \\
2\end{array}$ & $\begin{array}{c}\text { Strongly } \\
\text { disagree } \\
1\end{array}$ \\
\hline 49 & Learning spoken English is about speaking with confidence. & $\begin{array}{l}\text { Strongly } \\
\text { agree } \\
5\end{array}$ & $\begin{array}{c}\text { Agree } \\
4\end{array}$ & $\begin{array}{l}\text { Neutral } \\
3\end{array}$ & $\begin{array}{l}\text { Disagree } \\
2\end{array}$ & $\begin{array}{c}\text { Strongly } \\
\text { disagree } \\
1\end{array}$ \\
\hline 50 & Learning spoken English is about speaking without mistakes. & $\begin{array}{c}\text { Strongly } \\
\text { agree } \\
5\end{array}$ & $\begin{array}{c}\text { Agree } \\
4\end{array}$ & $\begin{array}{l}\text { Neutral } \\
3\end{array}$ & $\begin{array}{l}\text { Disagree } \\
2\end{array}$ & $\begin{array}{c}\text { Strongly } \\
\text { disagree } \\
1\end{array}$ \\
\hline 51 & Learning spoken English is about & $\begin{array}{c}\text { Strongly } \\
\text { agree } \\
5\end{array}$ & $\begin{array}{c}\text { Agree } \\
4\end{array}$ & $\begin{array}{l}\text { Neutral } \\
3\end{array}$ & $\begin{array}{l}\text { Disagree } \\
2\end{array}$ & $\begin{array}{c}\text { Strongly } \\
\text { disagree } \\
1\end{array}$ \\
\hline 52 & Learning spoken English is about & $\begin{array}{c}\text { Strongly } \\
\text { agree } \\
5\end{array}$ & $\begin{array}{c}\text { Agree } \\
4\end{array}$ & $\begin{array}{l}\text { Neutral } \\
3\end{array}$ & $\begin{array}{l}\text { Disagree } \\
2\end{array}$ & $\begin{array}{c}\text { Strongly } \\
\text { disagree } \\
1\end{array}$ \\
\hline 53 & Learning spoken English is about & $\begin{array}{l}\text { Strongly } \\
\text { agree } \\
5\end{array}$ & $\begin{array}{l}\text { Agree } \\
4\end{array}$ & $\begin{array}{c}\text { Neutral } \\
3\end{array}$ & $\begin{array}{c}\text { Disagree } \\
2\end{array}$ & $\begin{array}{c}\text { Strongly } \\
\text { disagree } \\
1\end{array}$ \\
\hline
\end{tabular}

\section{I.2. Part II}

In this part, we would like to know to what extent you agree or disagree with the statements below by circling a number from 1 to 5 . Please answer each item by circling the number in the boxes representing your extent of agreement with the statements.

\section{Attitudes towards autonomous learning}

55

56

57

58

60

61

62

63
I prefer studying English in a self-access way.

I prefer studying English at a language lab on my own.

I prefer studying English with peers

(e.g. classmates, friends at my age).

I prefer studying English with the teacher in the classroom.

I prefer studying English through extracurricular activities (e.g. Big Mouth corners, EDC English Drama Club, PIFS PolyU International Film Society, reading group etc.)

One problem with studying English is that classes are at fixed hours.

I like using visual aids and modern technologies.

A big problem in most English classes is that students have different levels.

If I had the right materials, I would prefer to spend some study studying alone.

\begin{tabular}{|c|c|c|c|c|}
\hline $\begin{array}{c}\text { Strongly } \\
\text { agree } \\
5\end{array}$ & $\begin{array}{c}\text { Agree } \\
4\end{array}$ & $\begin{array}{c}\text { Neutral } \\
3\end{array}$ & $\begin{array}{c}\text { Disagree } \\
2\end{array}$ & $\begin{array}{c}\text { Strongly } \\
\text { disagree } \\
1\end{array}$ \\
\hline $\begin{array}{c}\text { Strongly } \\
\text { agree } \\
5\end{array}$ & $\begin{array}{c}\text { Agree } \\
4\end{array}$ & $\begin{array}{c}\text { Neutral } \\
3\end{array}$ & $\begin{array}{c}\text { Disagree } \\
2\end{array}$ & $\begin{array}{c}\text { Strongly } \\
\text { disagree } \\
1\end{array}$ \\
\hline $\begin{array}{c}\text { Strongly } \\
\text { agree } \\
5\end{array}$ & $\begin{array}{c}\text { Agree } \\
4\end{array}$ & $\begin{array}{c}\text { Neutral } \\
3\end{array}$ & $\begin{array}{c}\text { Disagree } \\
2\end{array}$ & $\begin{array}{c}\text { Strongly } \\
\text { disagree } \\
1\end{array}$ \\
\hline $\begin{array}{c}\text { Strongly } \\
\text { agree } \\
5\end{array}$ & $\begin{array}{c}\text { Agree } \\
4\end{array}$ & $\begin{array}{c}\text { Neutral } \\
3\end{array}$ & $\begin{array}{c}\text { Disagree } \\
2\end{array}$ & $\begin{array}{c}\text { Strongly } \\
\text { disagree } \\
1\end{array}$ \\
\hline $\begin{array}{c}\text { Strongly } \\
\text { agree } \\
5\end{array}$ & $\begin{array}{c}\text { Agree } \\
4\end{array}$ & $\begin{array}{c}\text { Neutral } \\
3\end{array}$ & $\begin{array}{c}\text { Disagree } \\
2\end{array}$ & $\begin{array}{c}\text { Strongly } \\
\text { disagree } \\
1\end{array}$ \\
\hline $\begin{array}{c}\text { Strongly } \\
\text { agree } \\
5\end{array}$ & $\begin{array}{c}\text { Agree } \\
4\end{array}$ & $\begin{array}{c}\text { Neutral } \\
3\end{array}$ & $\begin{array}{c}\text { Disagree } \\
2\end{array}$ & $\begin{array}{c}\text { Strongly } \\
\text { disagree } \\
1\end{array}$ \\
\hline $\begin{array}{c}\text { Strongly } \\
\text { agree } \\
5\end{array}$ & $\begin{array}{c}\text { Agree } \\
4\end{array}$ & $\begin{array}{c}\text { Neutral } \\
3\end{array}$ & $\begin{array}{c}\text { Disagree } \\
2\end{array}$ & $\begin{array}{c}\text { Strongly } \\
\text { disagree } \\
1\end{array}$ \\
\hline $\begin{array}{c}\text { Strongly } \\
\text { agree } \\
5\end{array}$ & $\begin{array}{c}\text { Agree } \\
4\end{array}$ & $\begin{array}{c}\text { Neutral } \\
3\end{array}$ & $\begin{array}{c}\text { Disagree } \\
2\end{array}$ & $\begin{array}{c}\text { Strongly } \\
\text { disagree } \\
1\end{array}$ \\
\hline $\begin{array}{c}\text { Strongly } \\
\text { agree } \\
5\end{array}$ & $\begin{array}{c}\text { Agree } \\
4\end{array}$ & $\begin{array}{c}\text { Neutral } \\
3\end{array}$ & $\begin{array}{c}\text { Disagree } \\
2\end{array}$ & $\begin{array}{c}\text { Strongly } \\
\text { disagree } \\
1\end{array}$ \\
\hline
\end{tabular}




\section{Continued}

64

Contact with teachers should be used mainly

for speaking practice.

65

66

67

Teachers sometimes do not teach what students need to learn.

68

Grammar exercises and written homework are not necessary.

$\begin{gathered}\text { Strongly } \\ \text { agree } \\ 5 \\ \text { Strongly } \\ \text { agree } \\ 5\end{gathered}$
Strongly
agree
5
Strongly
agree
5
Strongly
agree

Agree
4
Agree
4

Agree
4

4
Agree
4

Agree Neutral

4

Neutra

3
Disagree

2

trongly

disagree

1

Strongly

disagree

1

Strongly

disagree

1

Strongly

disagree

1

Strongly disagree

\section{I.3. Part III}

Please answer the following questions related to your language learning experience and your implementation of the learning contract with at least 100 words for each answer.

1. Was the idea of self-access learning introduced in your secondary education?

How was the idea introduced? How did you learn English in a self-access way?

2. Do you consider yourself capable of learning English through ways like learning contract? Are you able to implement the learning contract as what are stated in your learning contract? Why or why not?

3. Are you ready for learning independently? Why or why not?

4. Does submitting learning evidence help you better fulfill the tasks stated in the learning contract? Why or why not? 
5. By the end of this learning contract, will you continue to use learning contract as a learning approach to improve your English language proficiency? Why or why not?

\section{Thank you for your participation!}

\section{Appendix II: Feedback for Students in the Learning Contract}

\section{Comments for Student A}

1. Make sure you know what to learn about a word in addition to its meaning (e.g. collocations, connotations, metaphorical extensions of meaning, etc). Remember to apply but not just writing down words in a vocabulary book.

2. What English articles are you going to read? How are you going to read in order to learn more vocabulary? Is it enough to do so only once a week? For how long each time?

3. What do you mean by grammar? It's too general and vague. Do you mean tenses? Or what? Why is grammar so important? What do you plan to do to improve?

4. Try to carry out the work in a step-by-step manner. The first step could be about reading relevant reference books. The second step should be about exposure (e.g. reading/listening to authentic texts) for analysis/critical thinking, and finally applications by producing something (could be writing or speaking).

5. Try to have a more specific plan of doing self-access work. If you can really follow this plan, you will expose to English more frequently in the course of the semester (more than 10 weeks). As President of CUHK emphasizes in the inauguration speech on 10 September to the students, "Your world will be much bigger than just the two sides of Victoria Harbour. Your interpersonal skills will be much improved...You will be much more mobile in your future career...You can find a job, build a career and establish a family anywhere around the world."

\section{Comments for Student B}

1. What do you mean by sentence structures? Do you mean you want to find out a variety of sentence structures to facilitate writing/speaking? This is actually very important as the use of variety of sentence structures is an indicator of high language proficiency level. Do you have in mind what sentence structures you want to learn? How to do so? Reading authentic texts and learning from their use of sentence structures? Please specify in your learning contract.

2. What do you mean by efficiency in listening? What are your problems in listening? Do you have difficulties getting the main idea? Is this a result of the use of slang/informal expressions/colloquial expressions? Developing a habit of listening in English is very good. You can give me a summary telling me what you heard from the programmes.

3. Learn the different approaches of listening (top-down, bottom-up) and see which one is more appropriate for you when you want to get the gist of what others said.

4. You can carry out the work in a step-by-step manner. The first step could be about reading relevant reference books. The second step should be about exposure (e.g. reading/listening to authentic texts) for analysis/critical thinking, and finally applications by producing something (could be writing or speaking).

5. Try to have a very specific plan of self-access work and follow it. If you can do the self-access work regularly in this semester, you will read many authentic texts (try to specify the frequency and number), and expose to English regularly in the coming three months. As President of CUHK emphasizes, "Your world will be much bigger than just the two sides of Victoria Harbour. Your interpersonal skills will be much improved...You will be much more mobile in your future career...You can find a job, build a career and establish a family anywhere around the world." 
Appendix III: Learning Contract 2010-2011 Academic Year (44 Students)

\begin{tabular}{|c|c|c|c|c|}
\hline $\begin{array}{c}\text { Skills } \\
\text { (out of } 44 \\
\text { students) }\end{array}$ & $\begin{array}{l}\text { Specific objectives } \\
\text { (responses) }\end{array}$ & Means/measures & $\begin{array}{l}\text { Frequency } \\
\text { (Token) }\end{array}$ & $\begin{array}{l}\text { Overall } \\
\text { (out of } 44 \\
\text { students) }\end{array}$ \\
\hline \multirow{8}{*}{$\begin{array}{l}\text { Writing } \\
\text { (20) }\end{array}$} & $\begin{array}{l}\text { - Appropriate use of (new) } \\
\text { words in writing (7) }\end{array}$ & $\begin{array}{l}\text { - Visit some exhibitions, learn new words and } \\
\text { apply them by writing reflective articles (1) } \\
\text { - Make a vocabulary notebook, jotting down } \\
\text { new words (with pictorial description) (2) } \\
\text { - Jot down every } 15 \text { new words learned and } \\
\text { make sentences of these words (1) } \\
\text { - Read newspapers (1) } \\
\text { - Write movie reviews and make comparisons } \\
\text { - with those written by critics (1) } \\
\text { - Go to cill (1) } \\
\text { - Read the english magazines written by native } \\
\text { speakers and learn the vocabularies they used (1) }\end{array}$ & $\begin{array}{l}7 / 24 \\
(29.2 \%)\end{array}$ & \multirow{8}{*}{$\begin{array}{l}20 / 44 \\
(45.5 \%)\end{array}$} \\
\hline & $\begin{array}{l}\text { - Use of various } \\
\text { sentence patterns (3) }\end{array}$ & $\begin{array}{l}\text { - Write an essay (1) } \\
\text { - Join writing competition (1) } \\
\text { - Send sms in english (1) } \\
\text { - Collect leaflets (1) } \\
\text { - Write regularly and go to cill } \\
\text { for improvement (2) } \\
\text { - Jot down good sentence structures } \\
\text { on a notebook (1) } \\
\text { - Browse the foreign websites more } \\
\text { frequently (1) }\end{array}$ & $\begin{array}{l}3 / 24 \\
(12.5 \%)\end{array}$ & \\
\hline & - Accuracy of writing (1) & $\begin{array}{l}\text { - Collect articles on the internet/magazines (1) } \\
\text { - Write at least one piece of writing per week (1) }\end{array}$ & $\begin{array}{l}1 / 24 \\
(4.2 \%)\end{array}$ & \\
\hline & - Summarizing skills (2) & - Watch TV drama and write a summary of that episode (2) & $2 / 24(8.3 \%)$ & \\
\hline & $\begin{array}{l}\text { - Structure and } \\
\text { organization (5) }\end{array}$ & $\begin{array}{l}\text { - Write reviews after reading books/watching } \\
\text { movies/dramas (3) } \\
\text { - Try to keep a diary so as to write in english more } \\
\text { frequently (1) } \\
\text { - Do more exercises on organization skills (1) } \\
\text { - Read more english novels (1) }\end{array}$ & $\begin{array}{l}5 / 24 \\
(20.8 \%)\end{array}$ & \\
\hline & $\begin{array}{l}\text { - Awareness of different } \\
\text { writing styles } \\
\text { and formats (3) }\end{array}$ & $\begin{array}{l}\text { - Participate in English writing competition (1) } \\
\text { - Write comments towards social issues monthly (1) } \\
\text { - Figure out different writing styles through reading novels, } \\
\text { magazines, formal letters or other sources and imitate } \\
\text { the writing styles to write some paragraphs for practice (2) }\end{array}$ & $\begin{array}{l}3 / 24 \\
(12.5 \%)\end{array}$ & \\
\hline & $\begin{array}{l}\text { - Effectiveness and } \\
\text { efficiency of writing (1) }\end{array}$ & - Read online articles/books in English (1) & $\begin{array}{l}1 / 24 \\
(4.2 \%)\end{array}$ & \\
\hline & $\begin{array}{l}\text { - Overall improvement } \\
\text { in writing (2) }\end{array}$ & $\begin{array}{l}\text { - Keep a habit of writing blogs and write } \\
\text { summary after watching English TV show (1) } \\
\text { - Read more books and newspapers in English (2) } \\
\text { - Write diary (1) } \\
\text { - Write book report or do newspaper cutting (1) }\end{array}$ & $\begin{array}{l}2 / 24 \\
(8.3 \%)\end{array}$ & \\
\hline $\begin{array}{l}\text { Listening } \\
\quad(15)\end{array}$ & $\begin{array}{l}\text { Listening comprehension/ } \\
\text { comprehension of the } \\
\text { conversation between } \\
\text { native speakers (15) }\end{array}$ & $\begin{array}{l}\text { - Watch English movies/dramas with (out) } \\
\text { subtitles and write reviews (7) } \\
\text { - Watch news report and write summaries afterwards (4) } \\
\text { - Write blogs based on the content of news (1) } \\
\text { - Listen to English songs and study the lyrics } \\
\text { and write comments about lyrics (1) } \\
\text { - Listen to the radio broadcasting in English and } \\
\text { write a summary afterwards (1) } \\
\text { - Watch movies and English video clips online (1) } \\
\text { - Transcribe the speech into text and jot down } \\
\text { slangs/colloquial words (1) } \\
\text { - Borrow some listening exercises books } \\
\text { (based on BBC News) (2) } \\
\text { - Pay special attention to the way native speakers talk (3) } \\
\text { - Make friends with native speakers of English (1) } \\
\text { - Seek for useful advice from others (1) } \\
\text { - Transcribe the drama in English (1) }\end{array}$ & $\begin{array}{l}15 / 17 \\
(88.2 \%)\end{array}$ & $\begin{array}{l}15 / 44 \\
(34.1 \%)\end{array}$ \\
\hline
\end{tabular}


Continued

\begin{tabular}{|c|c|c|c|c|}
\hline & - $\quad$ Note-taking skills (2) & $\begin{array}{l}\text { - Listen to the radio programme in English } \\
\text { and take some notes while listening (1) } \\
\text { - Take down notes when watching videos without subtitles (1) } \\
\text { - Write a summary based on the news content (1) }\end{array}$ & $\begin{array}{l}2 / 15 \\
(13.3 \%)\end{array}$ & \\
\hline \multirow{6}{*}{$\begin{array}{l}\text { Speaking } \\
\text { (38) }\end{array}$} & $\begin{array}{l}\text { - Pronunciation } \\
\text { - Accent (3) }\end{array}$ & $\begin{array}{l}\text { - Listen to radio programmes in English (e.g. BBC/RTHK etc.) } \\
\text { - Watch English movies/TV programmes (1) } \\
\text { - Record down the speech for improvement (1) }\end{array}$ & $\begin{array}{l}3 / 58 \\
(5.2 \%)\end{array}$ & \multirow{6}{*}{$\begin{array}{l}38 / 44 \\
(86.4 \%)\end{array}$} \\
\hline & $\begin{array}{ll}\text { - IPA(International } \\
\text { Phonetic Alphabet) } \\
\text { transcript (7) }\end{array}$ & $\begin{array}{l}\text { - Read aloud passages in newspapers or other scripts (6) } \\
\text { - Visit pronunciation websites and follow } \\
\text { the samples to pronounce words (1) } \\
\text { - Check ipa in dictionary (1) } \\
\text { - Watch speech delivered by famous speaker/celebrity online (1) } \\
\text { - Ask friends to correct the mistakes made in pronunciation (2) } \\
\text { - Imitate the pronunciations from the english } \\
\text { movies/ of native speakers (3) } \\
\text { - Communicate with others in English in daily life (1) }\end{array}$ & $\begin{array}{l}7 / 58 \\
(12.1 \%)\end{array}$ & \\
\hline & - Tones and intonations (1) & - Watch TV series/movies and imitate the actors' intonation (1) & $1 / 58(1.7 \%)$ & \\
\hline & - Accuracy (5) & $\begin{array}{l}\text { - Read aloud articles on newspaper/magazines } \\
\text { and record down (4) } \\
\text { - Imitate movie actor's way of speaking (1) }\end{array}$ & $\begin{array}{l}5 / 58 \\
(8.6 \%)\end{array}$ & \\
\hline & - Fluency (20) & $\begin{array}{ll}\text { - } & \text { Have discussions with friends in English } \\
\text { - } & \text { and record it down (6) } \\
\text { - } & \text { Imitate the way native speakers talk through } \\
& \text { watching movies/online videos (4) } \\
\text { - } & \text { Practice presentation in front of classmates (2) } \\
\text { - } & \text { Join Big Mouth Corner at polyu to practice oral English (2) } \\
\text { - } & \text { Visit CILL (1) } \\
\text { - } & \text { Give comments on newspaper articles and record it down (1) } \\
\text { - } & \text { Summarize the main ideas of books/movie/drama } \\
\text { - } & \text { after reading/watching (1) } \\
- & \text { Review movies/ books orally (1) } \\
- & \text { Pevelop the ability to think in English (1) } \\
- & \text { Retell stories to intonation (1) } \\
\text { - } & \text { Have discussion with (1) } \\
- & \text { Talk to instructor after class (1) } \\
- & \text { Do some voluntary job where English is used as a } \\
\text { - } & \text { medium for communication (1) } \\
- & \text { Read aloud the English news (2) } \\
\text { Read newspapers/magazines in English (1) }\end{array}$ & $20 / 58(34.5 \%)$ & \\
\hline & $\begin{array}{l}\text { - Confidence/language } \\
\text { competency (22) }\end{array}$ & $\begin{array}{ll}\text { - } & \text { Read aloud (e.g. At least } 2 \text { pieces of } \\
\text { articles/news/editorials written in english every day) (2) } \\
\text { - } & \text { Read more authentic materials and jot down } \\
\text { the new words and their meanings (2) } \\
\text { - } & \text { Talk with english native speakers (e.g. Native } \\
\text { speakers/exchange students at big mouth corner)/ } \\
\text { - } \quad \text { Hrite summary of the conversation (5) } \\
\text { - } & \text { Attend elep oral speaking class (1) } \\
\text { - } & \text { Practice presentation in front of classmates (1) } \\
\text { - } & \text { Watch drama series with(out) subtitles (1) } \\
\text { - } & \text { Use online platform to role-play and } \\
\text { - } & \text { practice spoken english (1) } \\
\text { - } & \text { Watch new words in animation/computer graphics (1) } \\
\text { - } & \text { Make use of different tools e.g. Mirror/web-cam and } \\
\text { record down the speech for improvement (2) } \\
\text { - } \quad \text { Give a at least 2-minute speech to the peers (1) } \\
\text { - } \quad \begin{array}{l}\text { Have more discussion with other students/peers/native } \\
\text { speakers in english (2) }\end{array} \\
\text { - } \quad \text { Watch online videos and tv programme in english, } \\
\text { jot down part of their scripts and check for the meanings (1) }\end{array}$ & $\begin{array}{l}22 / 58 \\
(37.9 \%)\end{array}$ & \\
\hline
\end{tabular}




\section{Continued}

\begin{tabular}{|c|c|c|c|c|}
\hline \multirow{3}{*}{$\begin{array}{l}\text { Reading } \\
\text { (9) }\end{array}$} & $\begin{array}{l}\text { - Reading comprehension } \\
\text { (4) }\end{array}$ & $\begin{array}{l}\text { - } \quad \text { Summarize the main ideas of the texts after reading } \\
\text { books/articles/watching movies (3) } \\
\text { - } \quad \text { Write comments after reading } \\
\text { books/articles/watching movies (1) } \\
\text { - } \quad \text { Take some notes when reading (1) }\end{array}$ & $\begin{array}{l}4 / 11 \\
(36.4 \%)\end{array}$ & \multirow{3}{*}{$\begin{array}{l}9 / 44 \\
(20.5 \%)\end{array}$} \\
\hline & $\begin{array}{l}\text { - Reading efficiency and } \\
\text { effectiveness } \\
\text { enhancement (e.g. } \\
\text { scanning and skimming } \\
\text { skills, reading speed) (6) }\end{array}$ & $\begin{array}{ll}\text { - } & \text { Record the time on finish reading passages (1) } \\
\text { - } & \text { Read newspapers/magazines/books and } \\
\text { - } & \text { Prite summaries after reading (3) } \\
\text { - } & \text { Read different types of texts on a regular basis (1) }\end{array}$ & $\begin{array}{l}6 / 11 \\
(54.5 \%)\end{array}$ & \\
\hline & $\begin{array}{l}\text { - Reading habit } \\
\text { cultivation (1) }\end{array}$ & $\begin{array}{l}\text { - Read English newspapers, } \\
\text { Academic journals and write reviews (1) }\end{array}$ & $\begin{array}{l}1 / 11 \\
(9.1 \%)\end{array}$ & \\
\hline \multirow{4}{*}{$\begin{array}{l}\text { Vocabulary } \\
\quad(21)\end{array}$} & $\begin{array}{l}\text { - Idioms and slangs } \\
\text { learning (2) }\end{array}$ & $\begin{array}{ll}\text { - } & \text { Watch movies/TV drama, documentaries and } \\
\text { - } & \text { jot down interesting expressions (1) } \\
\text { - } & \text { Try to use books about idioms and phrases to make new sentences (1) } \\
\text { - } & \text { Use the idioms and slangs learned in writing } \\
& \text { online blogs (1) }\end{array}$ & $\begin{array}{l}2 / 25 \\
(8.0 \%)\end{array}$ & \multirow{4}{*}{$\begin{array}{l}21 / 44 \\
(47.7 \%)\end{array}$} \\
\hline & $\begin{array}{l}\text { - Increase knowledge } \\
\text { related to phrasal verbs (1) }\end{array}$ & $\begin{array}{l}\text { - Find A Word List Of Phrasal Verbs, Memorize, } \\
\text { understand and apply these words in use (1) }\end{array}$ & $\begin{array}{l}1 / 25 \\
(4.0 \%)\end{array}$ & \\
\hline & $\begin{array}{l}\text { - Increase in vocabulary } \\
\text { size (20) }\end{array}$ & $\begin{array}{l}\text { - } \quad \text { Read authentic materials (e.g. Leaflet, newspapers etc.); } \\
\text { - } \quad \text { Chatch tv shows in english (5) } \\
\text { dictionary (1) } \\
\text { - } \quad \text { Collect different types of formal letter for reading (1) } \\
\text { - } \quad \text { Write down new words met in reading and make a } \\
\text { vocabulary notebook (2) } \\
\text { - } \quad \text { Jot down new words and use them in making new } \\
\text { sentences/writing comments on newspaper clippings (2) } \\
\text { - Find a word list of phrasal verbs, memorize, } \\
\quad \text { understand and apply these words in use (1) }\end{array}$ & $\begin{array}{l}20 / 25 \\
(80.0 \%)\end{array}$ & \\
\hline & $\begin{array}{l}\text { Acquirement of a specific } \\
\text { sort of vocabulary } \\
\text { (e.g. food vocabulary) (2) }\end{array}$ & $\begin{array}{ll}\text { - } & \text { Read more English news related to sports } \\
\text { and watch sports videos in English (1) } \\
\text { - } & \text { Jot down new words (1) } \\
\text { - } & \text { Try to write sports news (1) } \\
\text { - } & \text { Collect some guidelines or leaflets from shops/malls } \\
\text { and group the words on them } \\
\text { into different categories (1) }\end{array}$ & $\begin{array}{l}2 / 25 \\
(8.0 \%)\end{array}$ & \\
\hline \multirow{5}{*}{$\begin{array}{l}\text { Grammar } \\
\text { (8) }\end{array}$} & - Prepositions learning (1) & $\begin{array}{ll}\text { - } & \text { Do more grammar exercises (1) } \\
\text { - } & \text { Highlight the prepositions used in } \\
& \text { different articles (1) }\end{array}$ & $\begin{array}{l}1 / 9 \\
(11.1 \%)\end{array}$ & \multirow{5}{*}{$\begin{array}{l}8 / 44 \\
(18.2 \%)\end{array}$} \\
\hline & $\begin{array}{l}\text { - Correct use of } \\
\text { sentence structure (2) }\end{array}$ & $\begin{array}{ll}\text { - } & \text { Read grammar books to figure out proper } \\
\text { usages of sentence structures in different genre (1) } \\
\text { - } \quad \text { Borrow English grammar books to read (1) }\end{array}$ & $\begin{array}{l}2 / 9 \\
(22.2 \%)\end{array}$ & \\
\hline & $\begin{array}{l}\text { - Spelling accuracy } \\
\text { improvement (1) }\end{array}$ & $\begin{array}{ll}\text { - } & \text { Read newspapers and underline some words (1) } \\
\text { - } & \text { Write down the wrongly-spelled words and bear } \\
\text { in mind the correct spelling (1) }\end{array}$ & $\begin{array}{l}1 / 9 \\
(11.1 \%)\end{array}$ & \\
\hline & - Correct use of tense (1) & $\begin{array}{ll}\text { - } & \text { Do more grammar exercises (1) } \\
\text { - } & \text { Write some sentences (1) }\end{array}$ & $\begin{array}{l}1 / 9 \\
(11.1 \%)\end{array}$ & \\
\hline & $\begin{array}{l}\text { - An overall improvement } \\
\text { in grammar (4) }\end{array}$ & $\begin{array}{ll}\text { - } & \text { Frequently refer to grammar books when } \\
\text { - } & \text { Rriting summary of books/movies (1) } \\
\text { - } & \text { Read english grammar textbooks, memorize } \\
\text { the rules and try to apply them in writing blogs (1) } \\
\text { - } \quad \text { Read more grammar books and do some } \\
\text { proof-reading exercises (1) }\end{array}$ & $\begin{array}{l}4 / 9 \\
(44.4 \%)\end{array}$ & \\
\hline
\end{tabular}


Appendix IV: Learning Contract 2010-2011 SEM-2 ENGL 217 (57 Students)

\begin{tabular}{|c|c|c|c|c|}
\hline $\begin{array}{l}\text { Skills } \\
\text { (out of } 57 \\
\text { students) }\end{array}$ & $\begin{array}{l}\text { Specific objectives } \\
\text { (responses) }\end{array}$ & Means/measures & $\begin{array}{l}\text { Frequency } \\
\text { (Token) }\end{array}$ & $\begin{array}{l}\begin{array}{l}\text { Overall } \\
\text { (out of } 57 \\
\text { students) }\end{array} \\
\end{array}$ \\
\hline \multirow{5}{*}{$\begin{array}{l}\text { Writing } \\
(8)\end{array}$} & $\begin{array}{l}\text { - Appropriate use of } \\
\text { (new) words } \\
\text { in writing (1) }\end{array}$ & $\begin{array}{ll}\text { - } & \text { Do exercises (1) } \\
\text { - } & \text { Build a mini-database for expressions } \\
& \text { used in movies and research papers (1) } \\
\text { - } & \text { Search in corpus for usage of words (1) }\end{array}$ & $\begin{array}{l}1 / 11 \\
(9.1 \%)\end{array}$ & \multirow{5}{*}{$\begin{array}{l}8 / 57 \\
(14.0 \%)\end{array}$} \\
\hline & $\begin{array}{l}\text { - Use of various } \\
\text { sentence } \\
\text { patterns (3) }\end{array}$ & $\begin{array}{ll}\text { - } & \text { Jot down different kinds of sentence structures } \\
& \text { when reading newspapers, books, articles etc. (1) } \\
\text { - } & \text { Identify sentence structures in research papers (1) } \\
\text { - } & \text { Read book references about sentence structure (2) } \\
\text { - } & \text { Rewrite articles by using various sentence patterns (1) } \\
\text { - } & \text { Write diary and read many books (1) }\end{array}$ & $\begin{array}{l}3 / 11 \\
(27.3 \%)\end{array}$ & \\
\hline & $\begin{array}{l}\text { Awareness of } \\
\text { different } \\
\text { writing styles } \\
\text { and formats (5) }\end{array}$ & $\begin{array}{ll}\text { - } & \text { Read sample writings (1) } \\
\text { - } & \text { Watch TV programmes to learn how juniors } \\
& \text { should address to seniors (1) } \\
\text { - } & \text { Read English news and identify the nominalization (1) } \\
\text { - } & \text { Read book reference and follow its guideline } \\
& \text { to analyze formal writings' features (1) } \\
\text { - } & \text { Read grammar books and finish exercises (1) } \\
\text { - } & \text { Re-write news reports or listening } \\
& \text { materials like interviews (1) }\end{array}$ & $\begin{array}{l}5 / 11 \\
(45.5 \%)\end{array}$ & \\
\hline & $\begin{array}{l}\text { - Essay writing } \\
\text { skills (1) }\end{array}$ & $\begin{array}{l}\text { - } \quad \text { Read academic paper and analyze its word usages (1) } \\
\text { - } \text { Do exercises about academic writing style (e.g. quoting) (1) }\end{array}$ & $\begin{array}{l}1 / 11 \\
(9.1 \%)\end{array}$ & \\
\hline & $\begin{array}{l}\text { - Correct use of } \\
\text { punctuation mark (1) }\end{array}$ & $\begin{array}{ll}\text { - } & \text { Do exercises (1) } \\
\text { - } & \text { Read articles and analyze how } \\
& \text { punctuation marks are used (1) } \\
\text { - } & \text { Keep a record of what have been learned (1) }\end{array}$ & $\begin{array}{l}1 / 11 \\
(9.1 \%)\end{array}$ & \\
\hline \multirow{2}{*}{$\begin{array}{l}\text { Speaking } \\
\quad(2)\end{array}$} & $\begin{array}{l}\text { - Confidence/Language } \\
\text { competency (1) }\end{array}$ & $\begin{array}{l}\text { - } \quad \text { Talk to native speakers (1) } \\
\text { - } \quad \text { Watch dramas (1) }\end{array}$ & $\begin{array}{l}1 / 2 \\
(50 \%)\end{array}$ & \multirow{2}{*}{$\begin{array}{l}2 / 57 \\
(3.5 \%)\end{array}$} \\
\hline & - $\quad$ Presentation (1) & $\begin{array}{l}\text { - Watch presentations made by } \\
\text { famous scholars and practice at home (1) }\end{array}$ & $\begin{array}{l}1 / 2 \\
(50 \%)\end{array}$ & \\
\hline \multirow[b]{3}{*}{$\begin{array}{l}\text { Vocabulary } \\
\quad(37)\end{array}$} & - $\quad$ Metaphors (1) & $\begin{array}{ll}\text { - } & \text { Differentiate different types of metaphor (1) } \\
\text { - } & \text { Identify metaphor usages in the journal articles (1) }\end{array}$ & $\begin{array}{l}1 / 39 \\
(2.6 \%)\end{array}$ & \multirow[b]{3}{*}{$\begin{array}{l}37 / 57 \\
(64.9 \%)\end{array}$} \\
\hline & $\begin{array}{l}\text { - Increase knowledge } \\
\text { related to phrasal } \\
\text { verbs (1) }\end{array}$ & $\begin{array}{l}\text { - do exercises on grammar books with note-taking (1) } \\
\text { - practice the usages of phrasal verbs } \\
\text { in daily conversation (1) }\end{array}$ & $\begin{array}{l}1 / 39 \\
(2.6 \%)\end{array}$ & \\
\hline & $\begin{array}{ll}\text { - } & \text { Collocation } \\
& \text { learning (29) }\end{array}$ & $\begin{array}{ll}\text { - } & \text { Do grammar exercises (18) } \\
\text { - } & \text { Read book references and online materials } \\
\text { about collocation (12) } \\
\text { - } & \text { Read academic papers and articles to identify the } \\
\text { - collocation patterns and their meanings, functions (2) } \\
\text { - } \quad \text { Read newspapers and magazine articles } \\
\text { for authentic collocation patterns (11) } \\
\text { - } & \text { Get aware of the collocation pattern when writing essays (1) } \\
\text { - } & \text { Read well-written articles and learn } \\
\text { - } & \text { Do collocation patterns used (1) } \\
\text { - } & \text { patterns in the conversation or speech (1) } \\
\text { - } & \text { Write a report to summarize my findings (1) } \\
\text { - } & \text { Write sentences to practice each collocation pattern (3) } \\
\text { - } & \text { Jot down collocation patterns of words (2) } \\
\text { - } & \text { Watch TV news to jot down some commonly } \\
& \text { used collocations (1) } \\
\text { - } & \text { Watch movies to note down some collocation patterns (1) } \\
\text { - } & \text { Learn from some grammar books (1) } \\
\text { - } & \text { Use corpus to analyze words' collocation pattern (3) } \\
\text { - } & \text { Search and analyze collocations } \\
& \text { among different types of texts (1) } \\
\text { - } & \text { Ask teachers/classmates for advices (1) } \\
\text { - } & \text { Have discussions with others after reading books (1) } \\
\text { - } & \text { Keep a log book (1) } \\
\text { - } & \text { Write reflective essays (1) }\end{array}$ & $\begin{array}{l}29 / 39 \\
(74.4 \%)\end{array}$ & \\
\hline
\end{tabular}




\section{Continued}

\begin{tabular}{|c|c|c|c|c|}
\hline & $\begin{array}{l}\text { - Increase in } \\
\text { vocabulary size (4) }\end{array}$ & $\begin{array}{l}\text { - } \text { Read articles about a particular topic and jot } \\
\text { down the words learnt (1) } \\
\text { - } \\
\text { - } \\
\text { - Wead texts of different genres (especially the formal one) (1) } \\
\text { to enhance my understanding (1) } \\
\text { - } \quad \text { Read more English books and watch English movies, TV } \\
\text { programmes (1) } \\
\text { - } \\
\text { - } \\
\text { Build related exercises (2) } \\
\text { words among nocabulary bank by the most frequently used } \\
\text { synonyms (1) }\end{array}$ & $\begin{array}{l}4 / 39 \\
(10.3 \%)\end{array}$ & \\
\hline & $\begin{array}{l}\text { - A full mastery } \\
\text { of a word (2) }\end{array}$ & $\begin{array}{ll}\text { - } & \text { Do related exercises (1) } \\
\text { - } & \text { Read newspapers and magazines (1) } \\
\text { - } & \text { Analyse the use of words (1) } \\
\text { - } & \text { Look up for a word in both dictionary and corpus (1) }\end{array}$ & $\begin{array}{l}2 / 39 \\
(5.1 \%)\end{array}$ & \\
\hline & - Linking words (1) & $\begin{array}{l}\text { - Read book reference and finish follow-up exercises (1) } \\
\text { - Read articles for usages of linking words (1) }\end{array}$ & $\begin{array}{l}1 / 39 \\
(2.6 \%)\end{array}$ & \\
\hline & $\begin{array}{l}\text { - Acquirement of a } \\
\text { specific sort of } \\
\text { vocabulary } \\
\text { (e.g. food vocabulary) } \\
\text { (1) }\end{array}$ & - Read and collect a list of useful academic terms (1) & $\begin{array}{l}1 / 39 \\
(2.6 \%)\end{array}$ & \\
\hline & 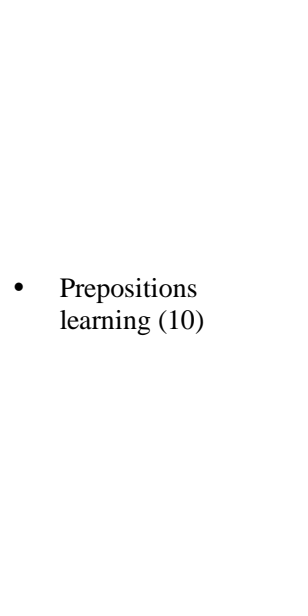 & 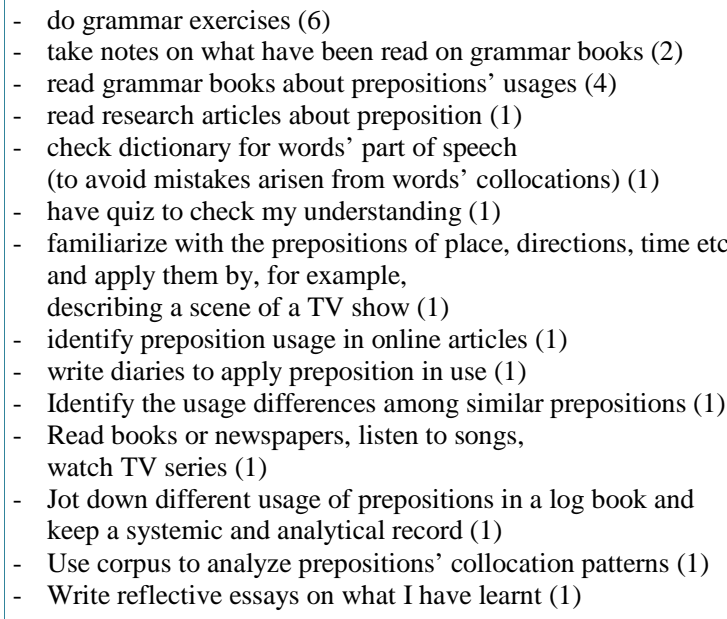 & $\begin{array}{l}10 / 64 \\
(5.6 \%)\end{array}$ & \\
\hline \multirow{3}{*}{$\begin{array}{l}\text { Grammar } \\
\quad(50)\end{array}$} & - $\quad$ Auxiliary verbs (1) & $\begin{array}{l}\text { - } \quad \text { write diaries to apply preposition in use (1) } \\
\text { - } \quad \text { do grammar exercises (1) }\end{array}$ & $\begin{array}{l}1 / 64 \\
(1.6 \%)\end{array}$ & \multirow{3}{*}{$\begin{array}{l}50 / 57 \\
(87.7 \%)\end{array}$} \\
\hline & - $\quad$ Modal verbs (8) & $\begin{array}{ll}\text { - } & \text { Read grammar books (5) } \\
\text { - } & \text { Do grammar exercises (7) } \\
\text { - } & \text { Collect some commonly used collocations } \\
\text { - } & \text { with examples of their usages (1) } \\
\text { - } & \text { Find authentic examples in newspaper articles/magazines } \\
\text { etc. and relevant information from online recourses } \\
\text { and grammar books; analyse the usages and } \\
\text { make up sentences using modal verbs (1) } \\
\text { - } & \text { Read articles to find authentic examples (2) } \\
\text { - } & \text { Ask teachers for advice (1) } \\
\text { - } & \text { Search and analyse the use of modal verbs } \\
\text { in different types of texts (1) } \\
\text { - } \text { Write essays using modal verbs and proof read it (1) }\end{array}$ & $\begin{array}{l}8 / 64 \\
(12.5 \%)\end{array}$ & \\
\hline & $\begin{array}{l}\text { - Correct use of } \\
\text { sentence structure (4) }\end{array}$ & $\begin{array}{ll}\text { - } & \text { read grammar books and do follow-up exercise (2) } \\
\text { - } & \text { read English newspapers, editorial or articles } \\
& \text { from magazines and jot down sentence patterns (3) } \\
\text { - } & \text { make up new sentences by using the sentence structures } \\
& \text { learned (1) } \\
\text { - } & \text { learn from book references about sentence pattern (1) }\end{array}$ & $\begin{array}{l}4 / 64 \\
(6.3 \%)\end{array}$ & \\
\hline
\end{tabular}




\section{Continued}

- Correct use of tense (23)
Learn tense (e.g. Definition) from grammar books (12)

Do grammar exercises (17)

- Identify the mistakes always made in doing exercise (1)

- Taking notes about different rules of grammar (2)

- Read newspapers/magazines for authentic examples about tense usages (5)

- Do writing and proof read it (2)

- Read an article and pay attention to the use of tense within the article (3)

- Collect texts of different genres to learn how to make proper choices of tense and report findings (1)

Search online for tense usages (2)

- Look for examples specific to my questions about tense usages (1)

- Identify tense usages from online articles (1)

- Read research articles to identify common mistakes made by esl learners and try to avoid them (1)

- Listen to radio program hosted by native speakers (1),

- Have discussions with others after reading books (1)

- Watch movies for tense usages in daily life (1)

- Do grammar exercise (4)

- Identify the mistakes always made in doing exercise (1)

- Read book references and online materials (1)

- Read newspapers and articles for authentic examples (3)

Write a short essays to practice(1)

- Conduct a corpus analysis on the part of speech using (2)

- $\quad$ Read newspapers, magazines to build up a word database of intransitive, transitive and diatransitive verbs; jot down sentence patterns and accurately use them in writing (1)

- $\quad$ Transitivity (1)

- Learn conditional clause (if) (2)

- Learn reporting statements (that-clause) from grammar books (1)

- Observe the usage of conditional clauses when doing regular readings (1)

- Clauses (2)

- Learn conditional clause (if) and reporting statements (that-clause) through doing exercises that specifically solve my problems (1)

- Do grammar exercises (3)

- Use book references and online materials (4)

Read newspapers (1)

- $\quad$ Read more research articles, essays (1)

- $\quad$ Ask teachers/classmates for advices (1)

$$
\text { - Plural and singular }
$$
forms of a word (1)

- Do grammar exercises (1)

- Passive/active voices (1)

- $\quad$ Do grammar exercise (1)

- $\quad$ identify the mistakes always made in doing exercise (1)

Read grammar books (1)

- Collect materials about this topic and archive them after reading (1)

- Infinite verbs (1)

- An overall improvement in grammar (1)
- Do grammar exercises to strengthen my grammatical skills (1) 